\title{
ENUMERATIO ÉS ÉKESSÉG ÁRKAY BERTALAN 1945 UTÁNI (USQUE) 12 TEMPLOMA ${ }^{1}$
}

"Árkay mérnök urat is megkeressük majd, mert szívünkön fekszik,
hogy stílusos ékességet nyerjünk szegénységünkben."

Az idézett mondat - amely egyszerre mutatja a korszakunk templomépítészetét meghatározó két tényezőt, vagyis az igényességet az esztétikai és a nehézkességet a materiális megformálásban - Vincze Dezső kakucsi plébános leveléből ${ }^{2}$ származik. Ám amennyire jól leírja a korabeli attitüdöt a mottó, annál nehezebb meghatározni, hogy pontosan hány templomot is épített Árkay Bertalan az 1945 utáni, szám szerint ${ }^{3}$ jelentős épületállományból. Dolgozatomban ${ }^{4}$ a Budapesti Történeti Múzeum Kiscelli Múzeumának Epítészeti Gyüjteményében őrzött tervanyag és levéltári források alapján erre teszek kísérletet, remélve ezáltal nemcsak az oeuvre teljesebb felvázolását, de az épületek, Árkay munkamódszerének és tervezői gyakorlatának alaposabb megismerését is. Ehhez az időrendben tárgyalt templomok építéstörténetének és terveinek ismertetése után megvizsgálom az épületek formai megoldásait, „ékességét" is.

Ârkaynak a Horton és Taksonyban épült templomaihoz ${ }^{5}$ képest a többiről gyérebb a szakirodalom, hisz csupán két feldolgozás tudósít ezekről az épületekről. Egyrészt Cséfalvay Pál említ 1988-as összefoglalásában ${ }^{6}$ Árkaytól négy templomot, másrészt Urbán Erzsébet és Vukoszávlyev Zorán két 2016-os cikkükben egyszer (a hortin és taksonyin kívül) tizenegy felépült templomról, és négy (öt) tervben maradtról írnak, ${ }^{7}$ másszor azt állítják, hogy Árkay „közel 20 templomot épített, illetve újított meg", ${ }^{\prime \prime}$ de végül ismét csak ugyanazt a tizenegyet tárgyalják. Árkay 1972-es nekrológja öt új építésü templomot és két újjáépítést nevez meg, amit az annak nyomán készült életrajzok is átvesznek. ${ }^{9}$

Az elsődleges források szintén ellentmondásosak. Az Építészeti Múzeumban őrzik Árkay Bertalan saját kezűleg írt műjegyzékét, amely tizenhét új templomról beszél. ${ }^{10}$ Az Árkay-hagyatékban megmaradt léptékes, méretezett tervrajzok és szabadkézi vázlatok, színes látványtervek (azonosított, és helyenként datált ${ }^{11}$ ) példányai, illetve a leltárkönyvek tanúsága szerint viszont 82 darab 1945 utánra tehető templomtervet készített Árkay, ami húsz helyszínhez köthető. Ebből tíz, Hortot és Taksonyt leszámítva pedig nyolc az 1945 utáni tervezésú új templom. ${ }^{12}$

A források ellentmondásossága akkor lesz feloldható, ha minden egyes épület szakirodalmi és/ vagy levéltári említését, tervanyagát forráskritikával kezeljük, és összevetjük a helyszínbejárások tapasztalataival is.

\section{ENUMERATIO}

1945-1953

Időben első Cegléd (Pest megye) Magyarok Nagyasszonya-temploma, ${ }^{13}$ amihez 33 tervet kapcsolnak az Építészeti Gyüjteményben. A legkorábbi az 1945. márciusi alapozási terv, a legkésőbbi datálás pedig 1949. novemberi, amin berendezés terve látható. ${ }^{14}$
A szentély, illetve a homlokzat kialakítása, valamint a toronyelhelyezés alapján a tervek három eltérő formai megoldást mutatnak. Mindegyik alaprajzon ${ }^{15}$ háromhajós templomot látunk, emelt szentélylyel, és abból nyíló négyzetes bővítményekkel. Ám míg az egyik szerint a szentély melletti kápolna és sekrestye félköríves bővülete közvetlenül a szen- 


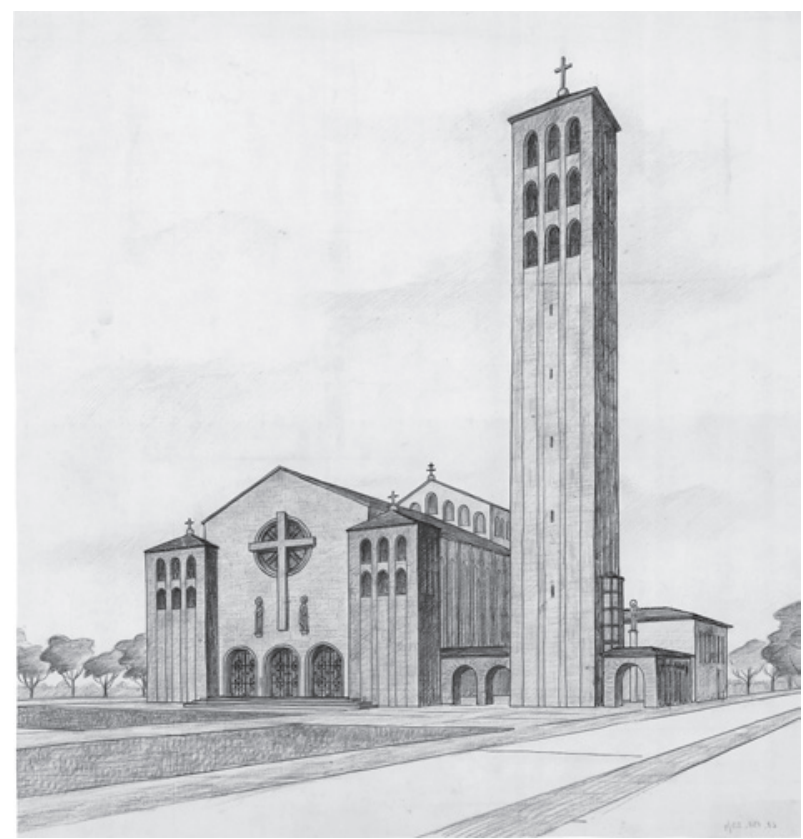

1. Árkay Bertalan: Ceglédi Magyarok Nagyasszonya plébániatemplom, távlat, 1947. Pausz, ceruza, színes ceruza, $60 \times 58$ cm. BTM KM ÉGy ltsz.: 68.138.23_4_1.

tély félkörívéhez csatlakozik, addig a másikon azok középvonalában helyezkedik el. Bár mindkettőhöz készült helyszínrajz, az alapozási terv az utóbbi egy (további félköríves bővítményekkel megtoldott) változata. A távlati rajzokon a nyeregtetős szentély a hajó fölé magasodik, és félköríves ablaksorral biztosítja annak megvilágítását. A homlokzat egyszerübb változatain három, illetve öt félköríves bejárat fölött kereszttel tagolt körablak nyílik. Az összetettebb megoldáson a főhajó és mellékhajók tömege elválik, és hol az előbbi, hol az utóbbiak előreugratásával teszi összetettebbé az épülettömeget. A bejárat mellett pilonszerüen álló tömböktől azok alacsony tornyokká alakításáig több elképzelés is született. ${ }^{16} \mathrm{~A}$ toronykialakításhoz Árkay két verziót rajzolt meg. $\mathrm{Az}$ egyiknél három sorban elhelyezett, keskeny félköríves ablakhármassal töri át a kontyolt torony felső szakaszát. A másiknál a négyzetes torony felső harmadánál karmos foglalatszerúen fogja közre a nyolcszögletü, félköríves ablakokkal áttört toronyszakaszt, amit hegyes sisak koronáz meg. A tornyok néhol a hajóhoz tapadva, másutt árkádokhoz csatlakozva állnak. A legösszetettebb tervváltozatnál a templom árkádos kerengőt és plébániaházat is kapott. $^{17}$

Az egyházközség első templomépítő bizottsága 1933-ban alakult. Akkor Fábián Gáspárt bízták meg a tervek elkészítésével. ${ }^{18} \mathrm{Az}$ építkezést szorgalmazó plébános halála miatt ez az elképzelés meghiúsult. Cegléd Újplébánia hivatalos kihirdetésére 1947 márciusában került sor, ${ }^{19}$ és áprilisban állt össze az új templomépítő bizottság, amely június 2-án kereste meg a város polgármesterét, hogy a Széchenyi úton levő városi telket templomépítés céljára adja át, és a volt Levente-otthon bontási anyagából téglát is juttasson az építkezéshez. Ekkor a polgármester a legmesszemenőbb támogatását ígérte meg, és június 9-i átiratában a plébános tudomására hozta, hogy „a kért telket a templomépítés céljára átengedi és 10e Ft értékben (kb. 40000$)$ téglát ad. ${ }^{20}$ A plébános körbekérdezte ismerőseit, hogy ki lenne a megfelelő tervező, majd püspökének is feltette a kérdést, hogy a beérkezett javaslatok közül kit válasszon? Módos Ferenc (a Farkasréti temető templomának tervezője, a Gellért Szálló müszaki főnöke), Fennesz László (a Központi Szeminárium újjáépítésének vezetője, a szegedi móravárosi templom tervezője), vagy (,ha történeti stílusban óhajtjuk a templomot megépíteni") Diebold Hermann építészek közül dr. Péterfy József püspök kit tart alkalmasnak a munkára? Ô továbbította a kérdést Dercsényi Dezső egyetemi magántanárnak, a Műemlékek Országos Bizottsága előadójának, aki a fentiekből Módost és Fenneszt ismerte, mint aki „pályázatokon szokott részt venni”. Ajánlotta viszont „Árkai (sic!) Bertalant, aki a városmajori, a győr-gyárvárosi és a mohácsi templomok építésével a legkiválóbb építészeink közé tartozik. Szép templom terveket és kivitelezett munkákat láttam Gerő Lászlótól, aki a székesfőváros magasépítési osztályán dolgozik épen (sic!) a kegyúri templomokkal, továbbá Megyer-Meyer Attilától (apácatornai, gyöngyösszőllősi templomok) valamint a Lechner családtól (Albertfalva)." Dercsényi úgy látja, hogy „mivel minden templomépítésnél a helyi adottságokat, szükségletet, a templomot látogató hívek ízlését etc. tekintetbe kell venni, a leghelyesebb az lenne, ha az ismertebb és kipróbáltabb tervezők közül néhányat felszólítanának tervek készítésére. Az ezzel kapcsolatos költségek bőven megtérülnének, hogy a célnak legjobban megfelelő, az egyházközség anyagi helyzetéhez képest a legjobbat lehet majd kiválasztani." ${ }^{21}$ Pályáztatásról a váci levéltárban nincsenek iratok, csupán Árkay megbízásáról. 1948. január 15-én terjeszti fel Tóth Tibor plébános jóváhagyásra a „háromhajós, neoromán, 1500 befogadóképességü templomtervet". ${ }^{22}$ Áprilisban már építik a templom szentélyét, a mellé csatlakozó sekrestyét és oldalkápolnát, és alattuk a kriptát. A tervek szerint őszre befejezték volna a $170 \mathrm{~m}^{2}$-es szentélyt, amit az iskolakápolna helyett azonnal használni szándékoztak. ${ }^{23} \mathrm{Az}$ anyagiak előteremtéséhez képeslap kiadására kértek engedélyt a püspöktől. ${ }^{24}$ Ezen a lapon láthatjuk, hogy a felsorolt tervváltozatok közül az épület jobb oldalához tapadó hegyes sisakos tornyú, de egyszerü, hármas tagolású hom- 


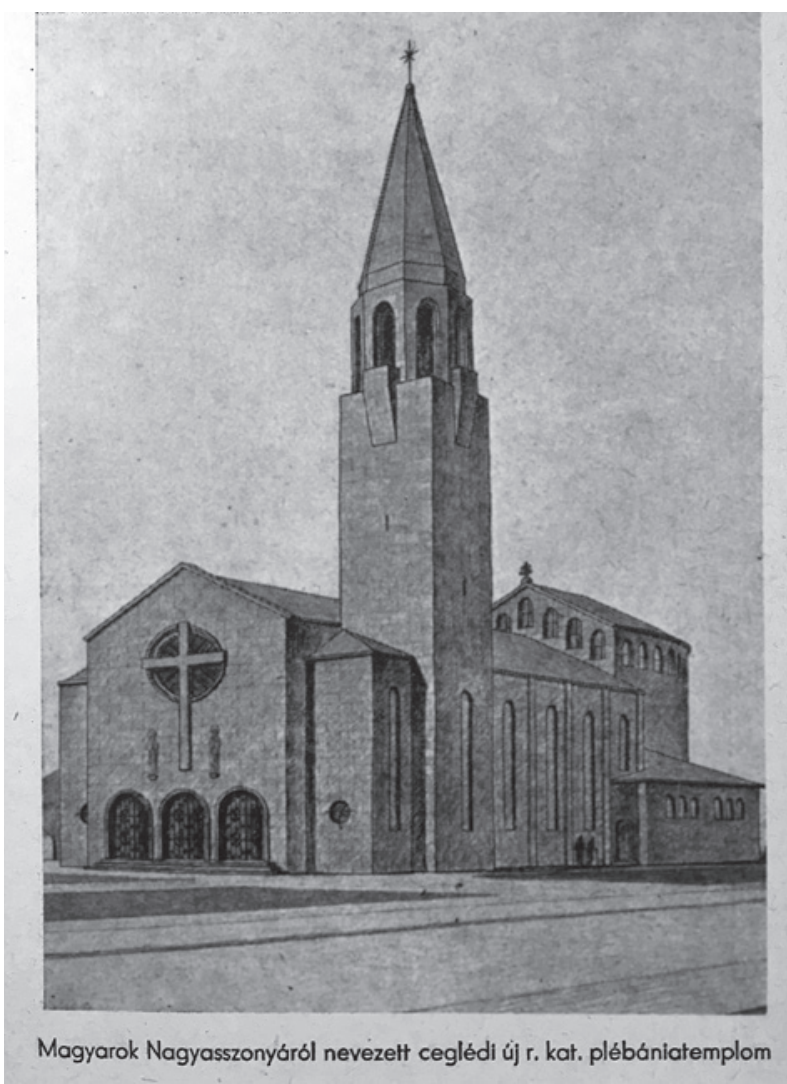

2. Árkay Bertalan: Magyarok Nagyasszonyáról nevezett ceglédi új r. k. plébániatemplom. Képeslap. VPKL AP Cegléd Újplébánia 2692/48.

lokzatverzió megvalósítását tüzték célul. Bár 1949. elején megszületett a város döntése a telekadományozás visszavonásáról (arra hivatkozva, hogy „,az ajándékozni kívánt ingatlan a város igen fontos helyén fekszik"), az egyházközség ősszel még megrendelte Árkaytól a gyóntatószék terveit. ${ }^{25}$ 1953-tól kezdve napirenden volt az épületrész lebontása, és miután 1957-ben a város a telket házhelyként eladta, a templomot végleg lebontották. ${ }^{26}$

Gerjen (Tolna megye) nyeregtetős, háromhajós, álbazilikális templomán a négyzetes alapú, felül nagy félköríves nyílásokkal áttört torony a főhomlokzat bal oldalára húzott. A templom szentélye félköríves. Főhomlokzatát a hármas, félköríves árkád és a fölötte nyíló rózsaablak, oldalait a mellékhajók keskeny, félköríves ablakpárjai határozzák meg. Tervanyaga 28 tervet és egy képeslapot tartalmaz, melyek nagyobb része feliratozott és datált. Az alap-, homlokzati és metszetrajzok mellett nagy számban találunk részletrajzokat is, ${ }^{27}$ amelyek szorosan köthetők a megépült épülethez. Két alaprajz, mindkét oldali fő- és szentély felőli homlokzatnézetek mellett több kereszt- és hosszmetszetet is találunk. A távlati kép kicsinyített, tusrajz verziója pedig képeslapként kapott új funkciót. ${ }^{28}$ A tervek, de

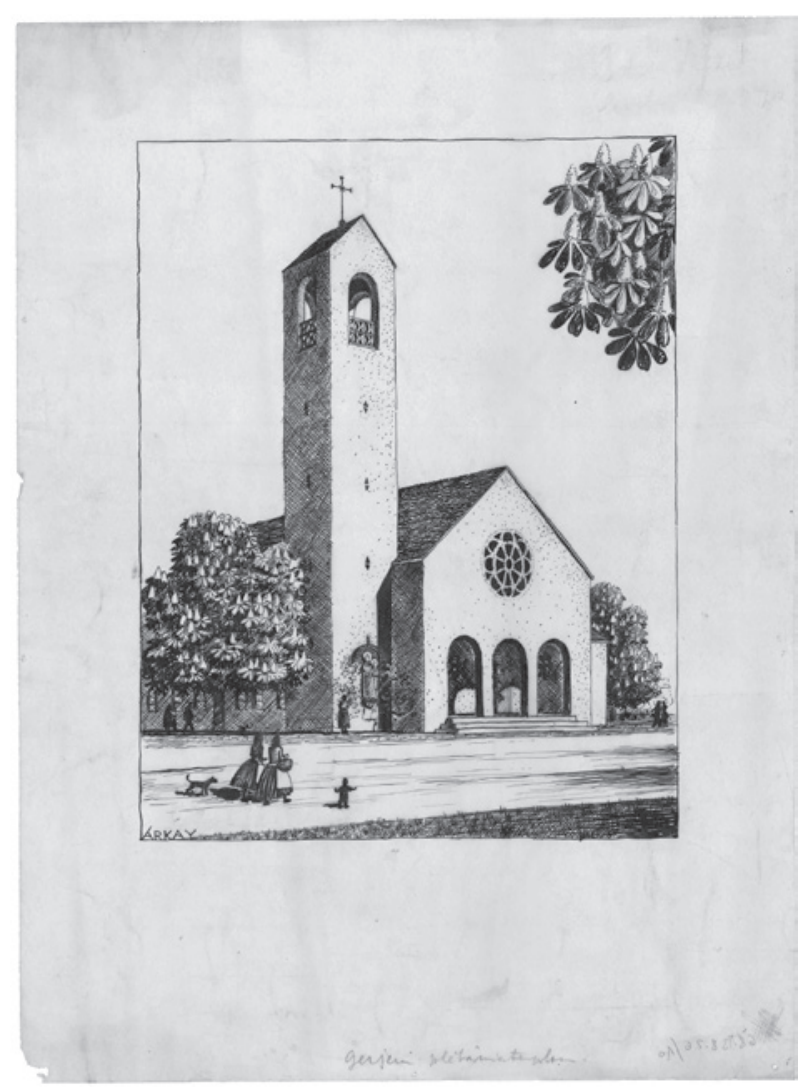

3. Árkay Bertalan: Gerjen, r. k. plébániatemplom terve, homlokzat és keresztmetszetek, 1948.

Pausz, ceruza, 29×40 cm. BTM KM ÉGy ltsz.: 68.138.26_10.

a rajzok is túlnyomórészt méretezettek, komolyabb variációkat itt nem találunk. A megvalósult állapot csak pár ponton különbözik az elképzelttől. Ilyen a kereszt elhagyása a nagy rózsaablak közepéből, és a bejárat melletti kis rózsaablakok leegyszerüsítése, a kevesebb ablakkal áttört kapu választása, a kóruskorlát tömör falas megoldása, vagy a szószék elmaradása. E jelentéktelennek tünő változtatások az eredeti terv kisszámú, de markáns díszeinek mellőzését jelentik.

Az egyházközségnek 1947-ben már megvolt a templomtelke, ${ }^{29}$ és noha Virág Ferenc püspök Tarai Lajos pécsi egyházmegyei építészt javasolta a tervek elkészítésére, 1948 májusában Árkay terve kapott tőle építési engedélyt. ${ }^{30} \mathrm{Az}$ alapkőletétel 1948. május 9-én volt, novemberben pedig már álltak a falak. ${ }^{31} 1949$. február és április közt készítette el Árkay a részletterveket, ${ }^{32}$ majd június 17-én felszentelték a még mennyezet és vakolás nélküli templomot. ${ }^{33}$

Kömpöc ${ }^{34}$ (Bács-Kiskun megye) temploma a föhomlokzat középtengelyébe állított toronnyal épült T alaprajzú, egyhajós, a szentélye két oldalán egyegy négyzetes bővítménnyel, és az azok vonalán kissé túlnyúló csapott sarkú szentélyzáródással 
képzett épület, oldalain három-három keskeny, félköríves ablakkal, a kórus vonalában egy-egy körablakkal, azok alatt kicsi, keskeny, félköríves ablakpárral. Árkay szerzőségét két terv ${ }^{35}$ és az írásos források is bizonyítják. A hagyaték méretezett tervén csupán egy homlokzati torony és a kórusábrázolás látható, amin a Gerjenből ismerős nyeregtetős, nagy, félköríves nyílással áttört toronymegoldás jelenik meg, az egyenes záródású kovácsoltvas kapu fölött pedig kereszttel tagolt félköríves ablak nyílik. A felépült homlokzat ettől eltért, hiszen a torony zömökebb, sisak fedi és csupán két lőrésszerü ablaka van, a bejárat pedig tömör fakapu egy kisebb lunettával, a két oldalán egy-egy szoborfülkével.

Az építkezés előkészületei már 1944-ben folytak, de a háború miatt csak 1949-ben kezdték el, ${ }^{36}$ s végül 1953. szeptember 20-án áldották meg a még nem teljesen kész templomot. ${ }^{37}$ 1955-ben Árkay tervezte a padokat és szentélyrácsot, ${ }^{38}$ amiket 1956 júniusában helyeztek el. 1957. augusztus 6-án állították fel a tervei szerint készített piszkei vörös márványoltárt, 1960-ban engedélyeztették az Egyházmegyei Hatósággal a Sztehlo Lili rajza után készült mozaik oltárképet. Itt, mivel „a terv elkészítése után nem sokkal a tervező művésznő tragikus körülmények között elhunyt, férje intézi, felesége hagyatékaként a fenti terv keresztülvitelét". A majdnem $3 \mathrm{~m}^{2}$-es, $140 \times 225$ cm-es oltárkép 1961-ben lett kész. ${ }^{39}$ 1962ben épült meg a szentély két oldalán álló sekrestye és oratórium. ${ }^{40}$

\section{7-1960}

Győr-Kisbácsa (Győr-Moson-Sopron megye) küklopsz falazatú, nyeregtetős homlokfalát az azt tagoló kereszt alakú ablak, és az annak hosszabb szárai mellé rendezett keskeny, alacsony, félköríves ablakpárok határozzák meg. A kéthajós templom szögletes szentélye szegmensívben záródik. Hajójának és szentélyének ablakai egyaránt nagyok és téglányalakúak.

Cséfalvay véleménye alapján „komolyabb szinten” álló, Urbán és Vukoszávlyev szerint „kompromisszumoktól mentes”, „ideálterv szerinti építkezés" ${ }^{41}$ volt Győr-Kisbácsa templomának megvalósulása, Hartmann pedig úgy véli, e templom „stílusával a római ókeresztény bazilikákhoz nyúlik vissza". ${ }^{42}$ Ehhez az épülethez a hagyatékban öt rajzot kötöttek. ${ }^{43}$ Ebből három pauszra készült tus tervrajz, ${ }^{44}$ egy pedig szignált homlokzatrajz. ${ }^{45}$ Mind a négyen ugyanaz a kéthajós, nyeregtetős, terméskő homlokzatos épület látszik. A templom emelt szentélye legyező alaprajzú, szegmensíves záródású. Míg a jobb oldalhomlokzaton a három, nagyméretü téglány ablak dominál, addig az épület bal oldalán, a szemközti ablaksorral megegyező hosszúságban nyúlik el a mellékhajó. Folytatásában előtér és kiszolgálóhelyiségek, valamint a sekrestye található. Árkay a mellékhajó bal oldalán kis kiülésü, alacsonyabb bővítményben helyezte el a gyóntatószékek fülkéit, fölöttük kisméretü, négyzetes ablakokat nyitott. A föhomlokzatot az egyenes záródású, előtetős kapuzat fölötti kereszt és az amellett elhelyezett ablakpárok határozzák meg. A mellékhajó árkádjai és a diadalív is egyenes záródású. A főhajó mennyezete kereszt irányban tagolt, lépcsőzetes kialakítású. A ceruzarajz annyiban különbözik a többitől, hogy a terméskő falszakaszok mellett vakolt részeket is kijelöl.

A korábban templomtalan község új templomának építkezése 1957. július 24-én kezdődött, az alapkőletétel ünnepe szeptember 8-án volt. Decemberre tető alá került a templom egy része, az első szentmisét advent kezdetekor a mellékhajóban végezték. ${ }^{46} \mathrm{~A}$ templom benedikálására 1958. szeptember 28-án került sor. ${ }^{47}$

A templomról fennmaradt egy olyan adománygyüjtő kép, amin a hajó bal oldalán egy árkádsorral kapcsolódó harangtorony áll, ${ }^{48}$ amely tervváltozatnak nincs nyoma a hagyatékban. Ettől eltekintve ez a templom lényegében a tervek szerint épült meg. ${ }^{49}$

Szalkszentmárton (Bács-Kiskun megye) temploma egyhajós, nyeregtetős épület, téglány alaprajzú szentéllyel. Oldalait a hármasával csoportosított keskeny, magas félköríves ablakok határozzák meg. Mennyezete két vízszintes, azok közt egy szegmensíves dongából áll. Nyílászárói vasszerkezetesek, kapuja kétszárnyú, kovácsoltvas. Homlokzatán a lépcsőzetes oromzaton felül öt, alatta három keskeny, félköríves nyílás, illetve ablak nyílik. Szögletes szentélye egyenes záródású. Keskeny, félköríves ablakai az oldalfalakon és a szentélyen is hármasával nyílnak. Erről a templomról három felirato ${ }^{50}$ tervet és huszonegy ${ }^{51}$ felirat és jelzet nélküli rajzot őriz a Kiscelli Múzeum Építészeti Gyűjteménye. Utóbbiak közül csak egy köthető kétségtelenül az építéstörténethez. ${ }^{52} \mathrm{Az}$ egyik azonosított terven helyszínrajz, fö- és oldalhomlokzat, alaprajz, kereszt- és hosszmetszet látható. A templom kéthajós, a főhajó nyereg-, a bal oldali mellékhajó félnyeregtetős épület. Szentélye szegmensíves. A hajó jobb oldalán négy keskeny, magas félköríves, a balon felül négy pár alacsony, keskeny félköríves, a mellékhajón pedig négy körablak található. A főhajónál kissé rövidebb, és abból félköríves árkádokkal nyíló mellékhajó folytatásában sekrestye nyílik. A homlokzatot a kereszt szárai közé komponált tizenkét szoborfülke határozza meg. A visszaugratott, egyenes záródású, kovácsoltvas kapu fölött vízszintes előtető hú- 


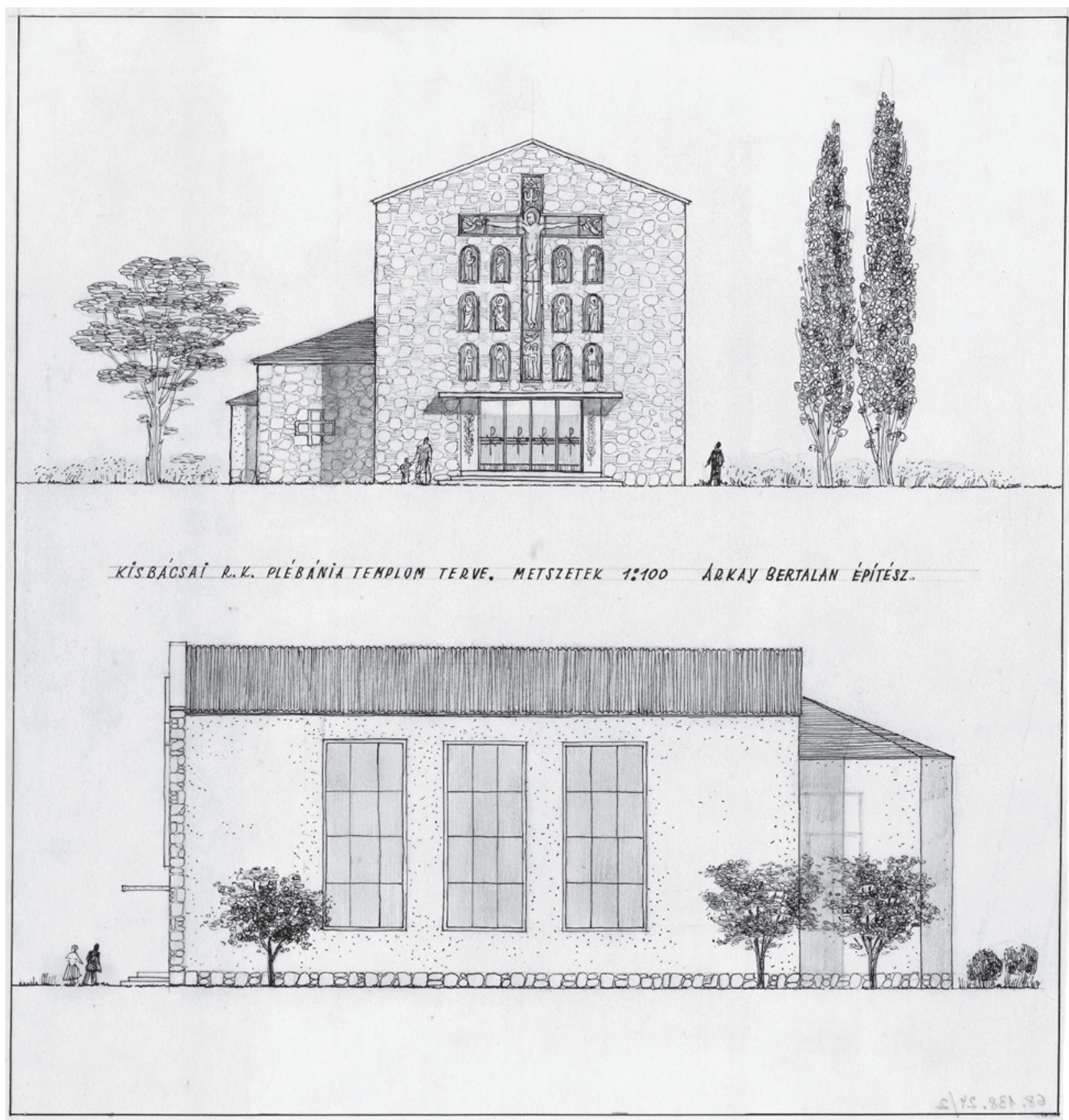

4. Árkay Bertalan: Kisbácsai templom, homlokzatok, 1957. Pausz, tus, 37×36 cm. BTM KM ÉGy ltsz.: 68.138.24_2.

zódik. A másik terv egy egyszerü, szinte lakóházhomlokzatú templom terve. Az egyenes záródású, négyszárnyú, kovácsoltvas kapuzat fölött egy nagyméretű, négyosztatú körablak az egyetlen dísz. Az egyhajós, egyenes szentélyzáródású, nyeregtetôs épület oldalhomlokzatát négy keskeny és magas félköríves, a szentélyt öt, közvetlenül az eresz alá helyezett kisméretü, keskeny, félköríves ablak tagolja. A harmadik terv egy részletesen méretezett homlokzatrajz. A kapuzat egyenes záródású, fölötte előtető, majd három, a lépcsőzetes oromzaton pedig öt keskeny, félköríves ablak nyílik.
1957 októberében az akkori lelkész azzal fordult az Egyházmegyei Hatósághoz, hogy szeretné felújítani a szükségkápolnájukat, emiatt dr. Kovács Vince, általános püspöki helynök Árkayhoz irányította őt az elvégzendő munka véleményezésére. ${ }^{53}$ Az összedőléssel fenyegető épület állapota miatt azonban 1958 januárjában már egy új templom építési engedélyét kérik Árkay tervei szerint. Az engedélyezési eljárás többszöri áttervezést igényelt, ${ }^{54}$ és 1958. szeptember 4-én járt sikerrel. Az építkezés a mezőgazdasági munkák miatt lassabban haladt. 1959 januárjában új pap, Regőczi István ${ }^{55}$ került az 


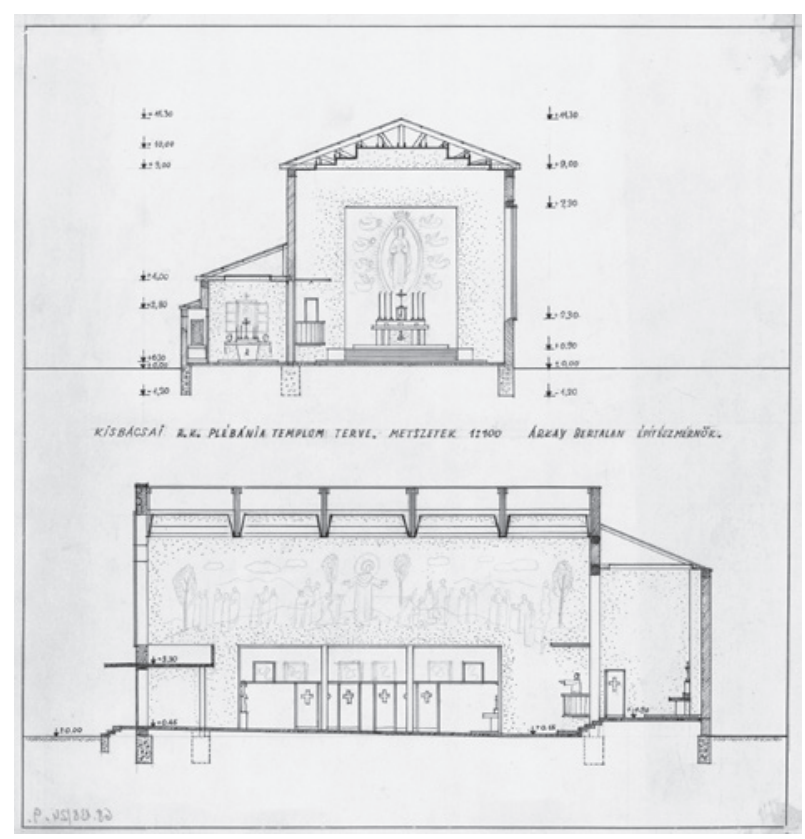

5. Árkay Bertalan: Kisbácsai templom, metszetek, 1957. Pausz, tus, $37 \times 36$ cm. BTM KM ÉGy ltsz.: 68.138.24_9.

egyházközség élére, aki lendületet ${ }^{56}$ adott az építkezésnek. Húsvétra a templom falai elértek a betonkoszorúig. ${ }^{57}$ A homlokzat áttervezését is Regőczi kérte Árkaytól, mert az eredetit túl egyszerünek vélte, és ragaszkodott ahhoz, hogy a templomnak templomkülseje legyen. Kérésre az épületet a „mérnök modern stílusban felfelé ívelő, három boltozattal képezte $\mathrm{ki}^{\prime \prime}{ }^{58} 1959$ márciusában már tető alatt volt a sekrestye, és a templomban ideiglenes misézőhelyet alakítottak ki. ${ }^{59}$

A hagyaték tervanyagának mindhárom feliratos variánsa megtalálta a helyét az építéstörténetben. A kéthajós épület tervén levő helyszínrajzon jól látható, amint a templom telekhatártól telekhatárig terjed, s annak szinte felét elfoglalja. Ez lehetett a túlméretezett, az egyszerü, körablakos verzió pedig a Regőczi által kifogásolt, míg a harmadikként ismertetett, méretezett példány a végül lépcsőzetes oromzattal megépült változat.

Vecsés (Pest megye) Andrássy-telepi temploma homlokzati tornyos, hajója széles, szentélye egyenes záródású, ablakai csúcsívesek. A kissé előreugró főhomlokzaton a kétszárnyú kapu rézsüs megoldású, fölötte nagyméretű körablak.

A hagyatékban 18 darab vecsési templom megnevezésú tétel van, de ebből csak a 15, pauszra készült tervrajz szignált és datált, illetve állítja magáról, hogy valóban Vecsésre készült. A maradék három $^{60}$ homlokzatvariáció. Öt terven a „Vecsési r. k. plébánia" ${ }^{\prime 61}$ felirat található. Ez utóbbi az Andrássytelepi plébániatemplom tervanyaga: egy alaprajz, egy fö- és egy oldalhomlokzati rajz, egy hossz-, egy pedig keresztmetszet az oltár felé. Mind az öt méretezett terv 1957-es. A terveken a torony záródása és a homlokzat kváderborítása kivételével a megvalósult templomot látjuk.

Vecsés Andrássy-telep plébániatemplomának építéséhez 1948-ban készíttetik el a terveket Kreybig László budapesti építésszel. A háromhajós,

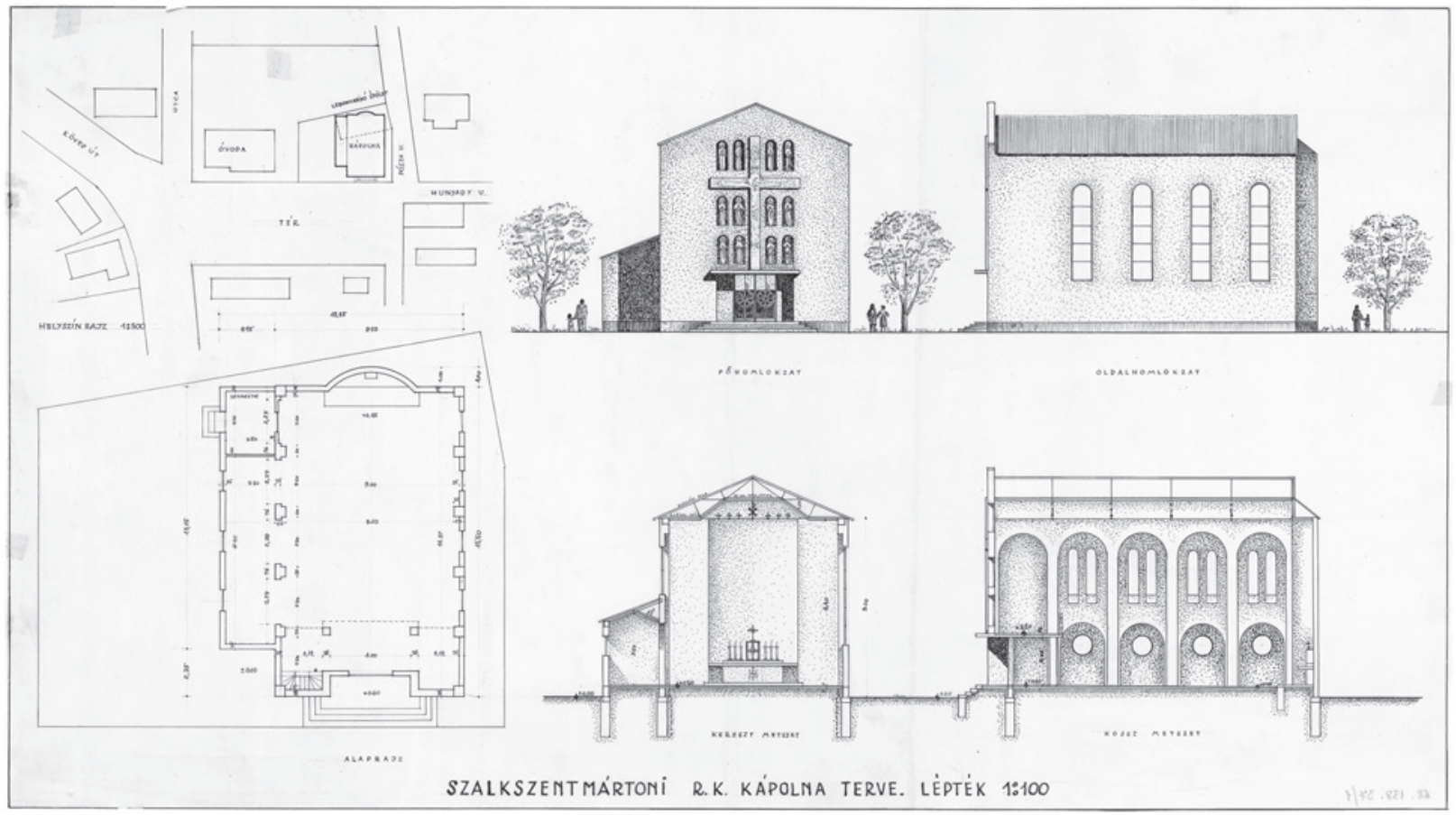

6. Árkay Bertalan: Szalkszentmárton, r. k. kápolna terve. Pausz, tus, $41 \times 73$ cm. BTM KM ÉGy ltsz.: 68.138.37_1. 


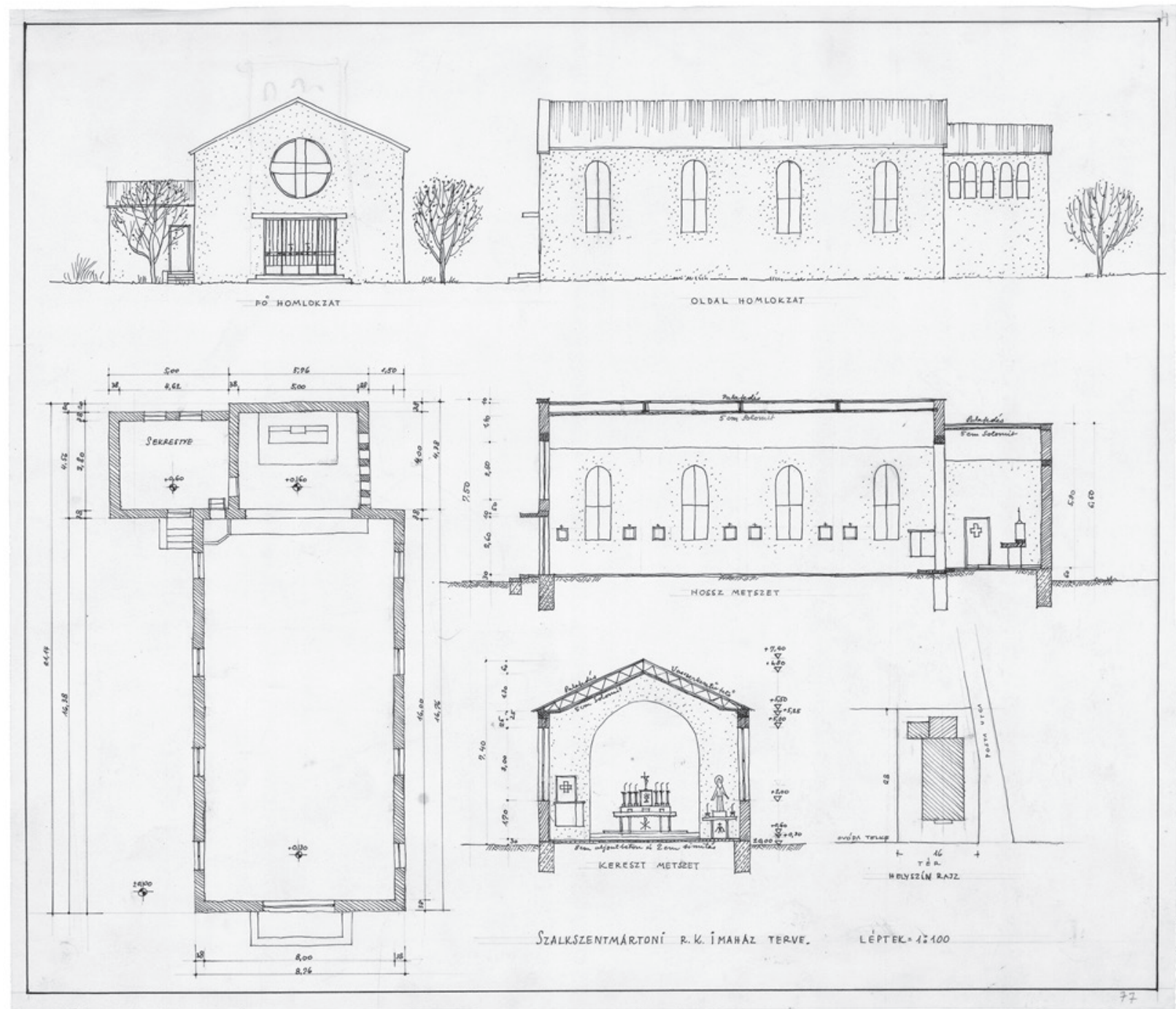

7. Árkay Bertalan: Szalkszentmárton, r. k. imaház terve. Pausz, tus, $42 \times 49$ cm. BTM KM ÉGy ltsz.: 68.138.37_2.

bazilikális, a főhajóban fiókos donga-, a mellékhajókban keresztboltozatos, homlokzati tornyos templom szentélye a nyolcszög három oldalával zárult. Tömegét a három szakasznyi hajó utáni kereszthajó és a homlokzati torony balján álló lépcsőtorony határozta meg. Külsejében az ablakpárokkal, valamint a vakíves párkánnyal a jáki templomot idézte. ${ }^{62} \mathrm{Az}$ év augusztusában megkapták ugyan az építési engedélyt, de csak azzal a feltétellel, ha átterveztetik olyanra, ami „,a korszerü stílustörekvéseket minden szempontból kielégíti." ${ }^{63}$ Kovács Alajos plébános emiatt felkereste az Építésügyi Főigazgatóság részéről Pogány Frigyes müszaki tanácsost és Gerevich Tibor egyetemi tanárt, akik többször is egyeztettek Kreybiggel, hogy végül szeptember elejére megszülessen a jóváhagyható terv. A templom háromhajós, az egyenes záródású szentély mellett sekrestyével, homlokzatának jobb oldalán négyzetes alapú toronnyal, bal oldalán lépcsőtoronnyal. A főhomlokzat egyszerü, az egyenes lezárású, kétszárnyú kapun kívül csak egy kisebb körablak díszíti. Oldalhomlokzatát négy félköríves ablak tagolja. ${ }^{64} \mathrm{~A}$ jóváhagyott terv alapján épülő templom alapkőletétele 1948. október 17-én volt. ${ }^{65} \mathrm{~A}$ plébános felvette a kapcsolatot a Notre Dame de Sion szerzetesnővérekkel, akik az alapkőszentelésen is részt vettek. Ők a háborúban megsérült templomuk ${ }^{66}$ harangját, $180 \mathrm{~cm}$-es carrarai márvány Mária-szobrát, térdeplőit, gyóntatószékét és építőanyagát ajánlották fel az építkezéshez. ${ }^{67} 1949$ őszére a sekrestye tető alá került, de a szentély és a hajó szentély felé eső falainak két szakasza is elkészült a koszorúig. A homlokzaton nagyjából a mai körablak alsó vonaláig állt a fal. 1950. június 15-i levelében a plébános arról értesíti az Egyházmegyei Hatóságot, hogy az épülő templom szentélyét ideiglenesen befedette, hogy jó idő esetén tudjanak ott misézni, de a templomépítés 


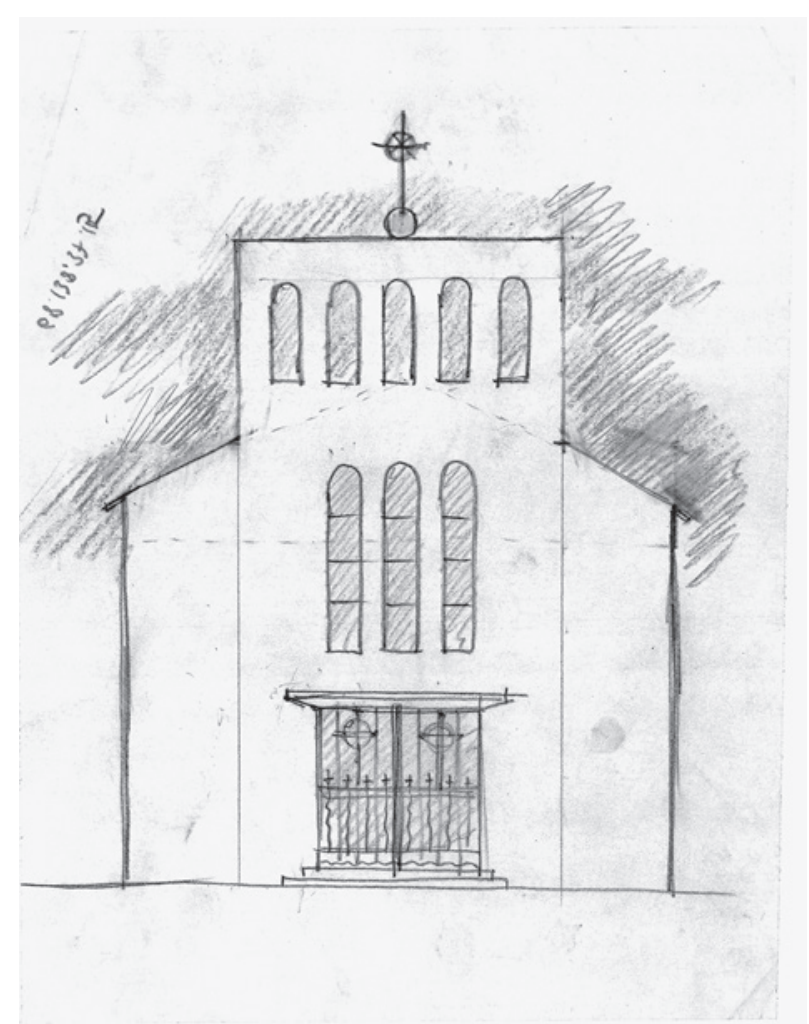

8. Árkay Bertalan: Szalkszentmártoni templom, homlokzat. Selyempapir, ceruza, szines ceruza, $32 \times 25 \mathrm{~cm}$. BTM KM ÉGy ltsz.: 68.138.37_15.

munkáját „akadályok miatt egyelőre” nem tudja folytatni. ${ }^{68} 1955-b e n$ az új plébános, Bognár Ferenc vette át a feladatot, ám 1956-ban kiderült, hogy az építési engedélyük lejárt. ${ }^{69} \mathrm{Az}$ engedélyezési procedúra ${ }^{70}$ során 1957-ben szakvéleményt kértek Árkay Bertalantól (akinek neve először szerepel az egyházmegyei iratokban ${ }^{71}$ ) az építkezés folytatásához. A legfontosabb lépés a betonkoszorú elkészítése volt a már álló szakaszokon, de végül a falazat teljes kiépítése és a vasszerkezetű lefedés mellett döntöttek. Árkay a személyesen látottak alapján elkészítette részletes javaslatait a templom továbbépítésére. Végül 1957 októberében kapták meg a hivatalos építési engedélyt. ${ }^{72}$ Még abban a hónapban megrendelték a Közúti Hídfenntartó Vállalattól a templomtető vasszerkezetét, amit az karácsonyra el is készített, és januárban felszerelt. ${ }^{73}$ A mennyezet terveit (amik „,Árkay mérnök úr és a Hídfenntartó Vállalat mérnöke közti megállapodás értelmében készültek"74) 1958 júliusában terjesztette fel Bognár az Egyházmegyei Hatósághoz jóváhagyásra, és szeptemberben készült el. ${ }^{75}$ A templom megáldására 1958. december 14-én került sor ${ }^{76}$ de hátra volt még a mennyezet kazettáinak felszerelése és a szószék kialakítása. ${ }^{77}$ 1962-ben fogtak hozzá a torony befejezéséhez. A terveket Szász Dezső építész és Cikora István okleveles építész, statikus mérnök írta alá. A 21 méterig felvitt torony felső negyedében, keskeny párkány fölött terméskő falazatban páros, csúcsíves nyílásokat alakítottak ki. ${ }^{78} \mathrm{~A}$ munkát 1962. november 9-én fejezték be. ${ }^{79}$ 1964-1965-re maradt a külső vakolás, és a lábazat kialakítása. ${ }^{80}$

A levéltári adatokat és az Árkay-hagyaték terveit összevetve, valamint az építkezés menetét dokumentáló fotók tanúsága szerint 1949-ben a homlokzat bal oldali kórusfeljárója nélkül, de a falak nagyobb része a csúcsíves, vasszerkezetes ablakokkal már készen állt. Tehát 1957-ben, mikor Árkay bekapcsolódott az építkezésbe, adott méreteket, épülettömeget, ablak- és kapukialakítást talált. Tervezői mozgástere a homlokzati körablak, a lefedés és (reményei szerint) a torony kialakításában volt csak. Azzal, hogy a torony megmagasításával 1962ben mást bíztak meg, az ő érdeme valójában mindössze az eredetinél nagyobb körablak és a tetőszerkezet, mennyezet kialakítása lehetett. ${ }^{81} \mathrm{~A}$ fentiek alapján hiába írja tehát 1957-ben az építkezést ismertető Doromby Károly (az Új Ember újságírója), ${ }^{82}$ de később Cséfalvay Pál is, hogy az Andrássy-telepi templom tervezője Árkay Bertalan volt, ${ }^{83}$ az ehhez a templomhoz készült tervrajzai nagy valószínűséggel az engedélyezési eljáráshoz készülhettek.

Hernád (Pest megye) templomának főhomlokzata oromzatos, amelyet egyetlen nagyméretü félköríves nyílás tör át. Alatta három keskeny félköríves ablak fut le az egyenes záródású kovácsoltvas kapu fölötti ívesen metszett vízszintes előtetőig. Oldalfalait hármasával álló, keskeny, félköríves ablakok nyitják meg. Szentélye a hajóval megegyező szélességü, sarkai kissé csapottak. Itt nem maradt fenn azonosított terv az Építészeti Gyüjteményben. Az, hogy Árkay nevéhez kapcsoljuk, a plébánia levéltári anyagán alapul.

Mivel korábban az iskolában és egy $6 \times 4$ m-es szobában/szükségkápolnában miséztek, 1957-ben új templom megépítéséhez kértek és kaptak engedélyt. ${ }^{84}$ A $25 \mathrm{~m}$ hosszú és $9 \mathrm{~m}$ széles templom alapkövét még az év augusztusában lerakták. Az Árkay ellenőrzése alatt folyó munka 1960 húsvétjára jutott el a gipszes vakolatú boltíves mennyezet kialakításáig és a kétszárnyú, kovácsoltvas kapu behelyezéséig. A külső vakolás és a belső kifestés itt is későbbre maradt. ${ }^{85} \mathrm{Az} 1960$. szeptember 4-i kápolnamegáldásról az Új Ember is beszámolt. ${ }^{86}$ Árkay tervezte az oltárukat is tardosi vörös és ruskicai fehér márványból 1963-ban. ${ }^{87}$

Inárcs (Pest megye) templomáról szintén nincs a hagyatékban terv. Az épület főhomlokzatát a sisakkal ellátott torony és a kereszt száraival elválasztott félköríves ablakpárok határozzák meg. Az egyhajós, félköríves szentélyzáródású templom oldalfalain keskeny, félköríves ablakpárok adják a vi- 
lágosságot. A nyeregtetős templom mennyezete két vízszintes sáv közt futó donga.

A csak iskolakápolnával rendelkező község 1956ban fogott neki a templomépítésnek. Az eredetileg templomként használt lakóház-szükségkápolna építési engedélyének intézését Vincze Dezső plébános 1956 júniusában kezdte meg, ${ }^{88}$ de végül csak 1957 márciusában jártak sikerrel. ${ }^{89}$ A telekkönyvezési bonyodalmak miatt a plébános azonnal megkezdi az építkezést, tehát amikor püspöki helynöke tanácsára ősszel megkeresi Árkayt, a 32 m hosszú és 9,1 m széles templom alapjai már készen voltak. ${ }^{90}$ 1958 tavaszán nekiálltak az építkezésnek, az alapkőszenteléskor, 1958. június 22 -én már betonkoszorúig álltak a falak. 1959 januárjában rendelték meg a tető vasszerkezetét, októberben pedig már a tornyot építik. ${ }^{91} 1960$-ra készült el a belső vakolás, a villanyszerelés, de az év végére elakadt a toronyépítés. ${ }^{92}$ A templom benedikálását 1962. szeptember 9-én végezték. $^{93}$

Móricgát (Bács-Kiskun megye) templomának föhomlokzatát a nyeregtető szögét követő, de jócskán afölé magasodó oromzat határozza meg, melyet három keskeny, félköríves nyílás tör át. Szögletes szentélyének végfala kétoldalt keskeny egyenes szakasz közül induló szegmensívben záródik. Ehhez a templomhoz hat tervet öriz a gyüjtemény. ${ }^{94}$ Kettő, az alap- és helyszínrajzot, valamint a homlokzatokat, metszeteket megjelenítő méretezett, pauszra készült szignált tusrajz. A többi fekete, illetve színes ceruzával készült homlokzati vázlatrajz. Ezek közül csupán egy az, ami valóban köthető Móricgáthoz. ${ }^{95}$ A két ceruzavázlat négy templomhomlokzata egyaránt terméskő falazattal, nagyméretü, félköríves fa kapuzattal, szinte vízszintes oromzattal és hármasával csoportosított félköríves nyílásokkal készült. ${ }^{96}$ Bár Móricgáton - lévén kiskunsági település - maga a terméskő falazat is idegenszerü, ${ }^{97}$ nehéz magyarázatot találni arra, hogy a szintén móricgátiként azonosított negyedik vázlat miként társítható a településhez. A közel vízszintes oromzatos templomot árkádos folyosó köti össze a jobb oldalon álló méretes toronnyal, és a terméskő falazatú épületcsoport mögött hegyláncok magasodnak. ${ }^{98}$

Árkay Bertalan 1957. szeptember 10-én még csak az eredeti, 1911-ben emelt ${ }^{99}$ vályogfalú templom felújításához ad szakértői véleményt, ám a helyi Tanács időközben egy másik szakértői véleményre hivatkozva a templom lebontásáról és új építéséről döntött. ${ }^{100}$ 1958. május 13-án terjesztették be az új templom tervét ${ }^{101}$ az Egyházügyi Hivatalhoz. És bár a megyei egyházügyi előadó maga is szorgalmazta az építkezést, és elismerte az életveszélyes állapotokat, ${ }^{102}$ az építési engedélyt csak július köze-

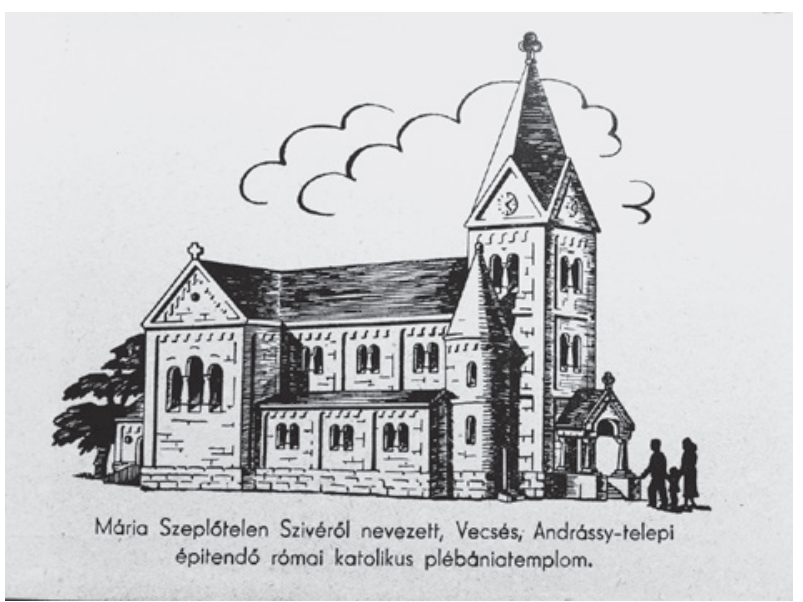

9. Kreybig László: Mária Szeplőtelen Szívéről nevezett, Vecsés, Andrássy-telepi épitendô római katolikus plébániatemplom 1. Képeslap. VPKL VII. Gyüjtemények 3. B. V. Vecsés

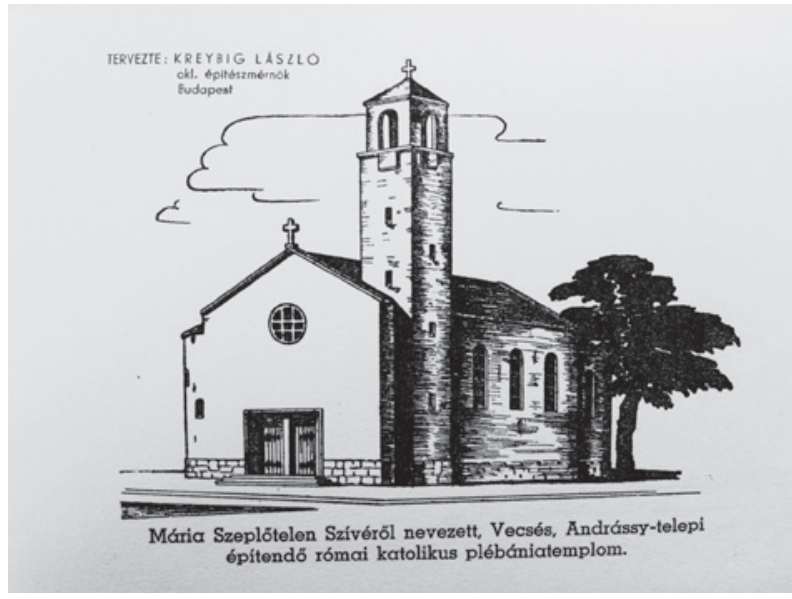

10. Kreybig László: Mária Szeplőtelen Szívéről nevezett, Vecsés, Andrássy-telepi épitendő római katolikus plébániatemplom 2.

Képeslap. VPKL VII. Gyüjtemények 3. B. V. Vecsés

pén adták ki. 1958. szeptember 9-én kezdték meg az alapkijelölést, és az alapozási munkákat, így amikor 1958. október 19-én lerakták az alapkövet, már embermagasság fölött álltak körben a falak. Ugyancsak 1958 szeptemberéből ismeretes egy rajz, amit Kónya küldött el az Egyházmegyei Hatóságnak, és „mely a tervezett templom rajzáról készült". ${ }^{103}$ Ezen a templom homlokzata megegyezik a megépülttel, de balról egyszakaszos árkád köti össze a négyzetes alaprajzú, felül nagyméretü félköríves nyílással ellátott, nyeregtetős toronnyal. ${ }^{104} \mathrm{~A}$ pénzszűke ellenére 1959 decemberében már a templom felszenteléséről tudósít az Új Ember. ${ }^{105}$ 1960-ban elkészült a külső vakolás is.

Itt csak annyi az eltérés a hagyatékból ismert tervtől, hogy nem a szentély bal, hanem annak jobb oldalára épült fel a sekrestye, ami íves ablakok helyett szögletest kapott, és a bejáratát is máshová he- 


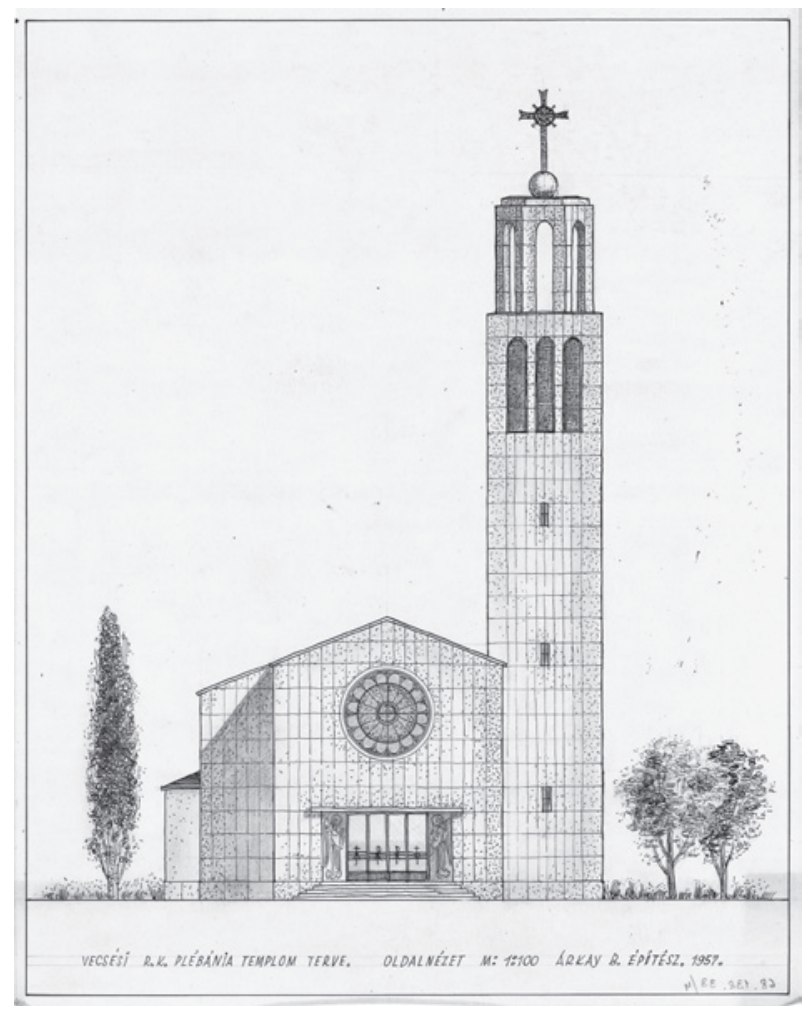

11. Árkay Bertalan: Vecsési r. k. plébániatemplom terve, föhomlokzat, 1957. Pausz, tus, $44 \times 34 \mathrm{~cm}$. BTM KM ÉGy ltsz.: 68.138.33_4.

lyezték. A hajó mennyezete nem két szélső vízszintes szakasz közti szegmensíves lefedés, hanem két, a nyeregtető szögét követő és egy harmadik, vízszintes elemből áll. A diadalív sem szegmens-, hanem félköríves, és hiányzik a szószék. Az egyenesnek tervezett szentélyzáródás helyett két keskeny egyenes szakasz közti szegmensív van, oldalfalán pedig nem három kisebb, csupán egy pár keskeny, magas, félköríves ablak nyílik.

Tiszalök (Szabolcs-Szatmár-Bereg megye) templomáról csak tervet ismerünk. ${ }^{106} \mathrm{Az}$ egyhajós, egyenes szentélyzáródású templom oldalhomlokzatain keskeny, félköríves ablakok nyílnak. Főhomlokzatán az egyenes záródású pengefalon a kovácsoltvas kapu fölött angyalmotívum, majd öt keskeny, félköríves nyílás található. Tiszalök templomát a visszavonuló németek robbantották fel, és bár 1947-től vannak törekvések templomépítésre, ${ }^{107} 1959$. augusztus 14-re jutottak el addig, hogy Árkay műleírást készített a templomhoz. ${ }^{108} \mathrm{Az}$ építkezés az anyagiak szükössége és községrendezési okokból hiúsult meg. ${ }^{109}$

Újtikos (Hajdú-Bihar megye) plébániatemplomtervén ${ }^{110}$ egyhajós, sokszögzáródású szentélyes, nyeregtetős, homlokzati tornyos épület látható. A homlokfal és a torony kváder falazatú, a templom többi része a kváderes lábazat fölött vakolt. A hajó két oldalán keskeny, félköríves ablakpárok- kal tagolt, a nyeregtetőn az ablakközökben háromszög alakú tetőablakok. A szentélyt három lépcsővel emeli meg, a diadalív félköríves. Az alaprajz a szentély mindkét szélső falszakaszán keskeny, félköríves ablakokat jelöl, ezek közül az egyik az oldalhomlokzat rajzán hiányzik. A toronyaljában kétszárnyú, félköríves fakapu nyílik, fölötte keresztosztású körablak. A tornyot a homlokzati és az azzal átellenes oldalán nagyméretü, félköríves ablak nyitja meg.

A település 1942-ben lett önálló plébánia. 1943ban iskolakápolna, majd templom építéséről döntöttek. ${ }^{111}$ 1943-ban a Földművelésügyi Minisztérium és az Egri Főegyházmegye tervpályázatot írt ki Tikos és Nagyút templomaihoz. Az öt legfontosabb követelmény a "takarékos beépítés”, a könnyű bővítési lehetőség, a szerkezet (főként a fenntarthatósági költségek szempontjából) helyes megválasztása, „a népies és magyar táji jelleg kidomborítása” és „, típus jelleg, vagyis a több helyen való felhasználás lehetősége" 112 volt. Táby Ervin, Kollár Gyula, Hevesy Sándor, Brestyánszky Tibor és dr. Vitéz Kiss Tibor pályáztak, és Kollár tervét vették meg. Bár az építőanyagot összegyűjtötték, azt a háború elvitte, így csak 1958-ban kezdhettek újra a templomépítéshez. ${ }^{113}$ Bodnár Barnabás tiszagyulaházi plébános kérte az építési engedélyt, amit meg is kaptak, de Eszes István tiszafüredi ács és kőmüves tervében a müszaki hatóságok hibát találtak, így csak a „második - mérnöki közreműködéssel készült - tervrajz" nyert jóváhagyást. A szerkezetileg toronyépítésre is alkalmas terv ${ }^{114}$ alapján 1958. augusztus 31én elkezdték az építkezést. 1959. november 15-én Brezanóczy Pál apostoli kormányzó szentelte fel a templomot. ${ }^{115}$ 1961-ben végeztek a külső vakolással. A megépült épület oldalhomlokzatának ablakai méretükben, számukban, illetve a torony félköríves és körablakai helyett azok szögletes kialakításában eltér a látott tervtől. ${ }^{116}$ Egyezik azonban a templom méretezése, ${ }^{117}$ a tömeg és a homlokzati kereszt, valamint a kapu lényegi kialakítása. Noha a plébániai honlap szerint egyáltalán nem is történt építkezés, ${ }^{118}$ Árkay terve, müjegyzéke, az Egri Főegyházmegyei Levéltár fotó- és iratanyaga alapján az épület (ha nagyon szigorúak akarunk lenni, akkor legalábbis áttervezés szinten) Árkayhoz köthető.

Vecsés - Óplébánia (Pest megye) Szent Kereszt Felmagasztalása-templomának homlokzatát a nyeregtető szögét követő zárt, vakárkádos oromzat dominálja. Hajójának jobb oldalán két fülke között félköríves kápolna kapott helyet, szentélye keskeny, egyenes szakaszok közt íves záródású, ablakai szélesek, szintén félkörívesek.

Árkay vecsésiként azonosított tervei közül tízen szerepel az óplébánia név, amiből hét a „Vecsési 


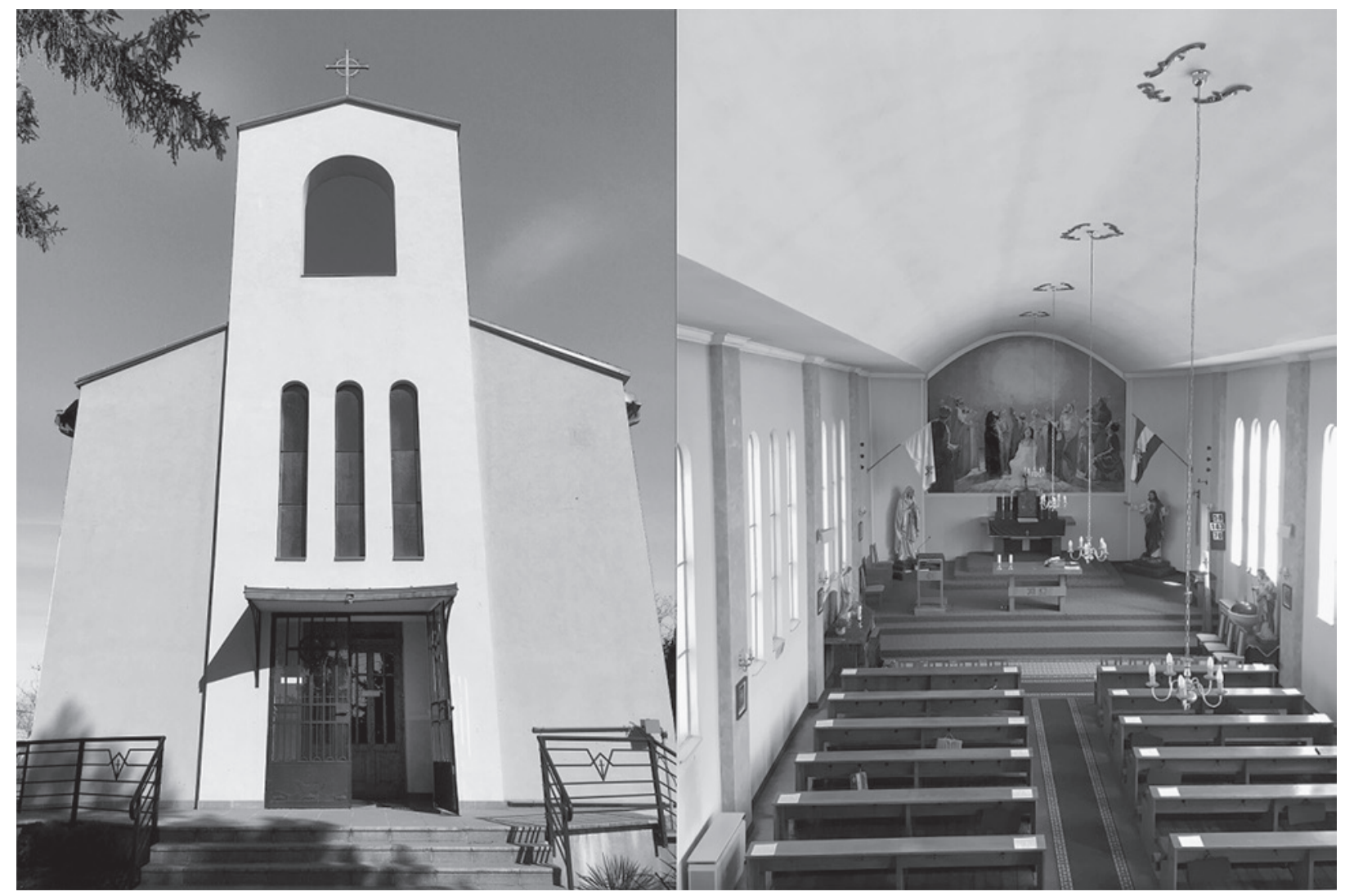

12. Hernád, templom (fotó: Lantos Edit)

(r. k.) Óplébánia templom helyreállítási terve", ${ }^{119}$ a többi ${ }^{120}$ (alaprajz, fó- és oldalhomlokzat, kereszt- és hosszmetszet) a "Vecsési r. k. Óplébánia építkezése" címet viseli. A helyreállítási tervek (alaprajz, hossz- és keresztmetszet, hátsó-, két oldal- és a főhomlokzat) egy kéthajós, kívülről egyenes szentélyzáródású templomot mutatnak. A mellékhajó hossza a főhajó kétharmada, és annak bal oldalán, attól három pillérrel elválasztva található. A négy szakasznyi tér folytatásában a sekrestye és a raktár nyílik. A lépcsőkkel megemelt szentély belül íves, fülkés kiképzésű. Az aszimmetrikus alaprajz az oldalhomlokzatok kialakításában a legszembetünőbb: míg a templom jobb oldalát hat magas, félköríves és egy körablak tagolja, addig a bal oldalon alul négy görög kereszt alakú, fölül hét körablak nyitja meg a falakat. A főhomlokzat és a hátsó nézet $^{121}$ az oldalhomlokzatok terveivel szemben nem nyeregtetős, hanem lapos tetős hajót (vagy legalábbis egyenes záródású oromzatot ${ }^{122}$ ) mutat. A lapos tetős alacsonyabb mellékhajók fölé a teljes magasság egy ötödével magasodó középrészen a két szegmensíves kapu közt konzolon álló szobor kapott helyet. Mögüle indul a latin kereszt motívum, amelynek két szára mellett egy-egy nagyméretü félköríves ablak, a szárak találkozásánál pedig egy körablak látható.
A másik tervanyagból egy T alaprajzú, egyhajós, nyeregtetős, az íves záródású szentély két oldalára szimmetrikusan elhelyezett alacsonyabb kiszolgáló helyiségekből, a hajó jobb oldalán pedig a két-két oszloppal tagolt "gyóntatószék" elnevezésű fülke közé illesztett félköríves, lapos tetôs kápolnából komponált templom tűnik elő. Az emelt szentély alatt altemplom ${ }^{123}$ van, a hajót és a szentélyt is 3-3 magas, félköríves ablak és az azok melletti négy pilaszter tagolja. A főhomlokzaton egyenes záródású, díszes kovácsoltvas kapu, afölött előtető és kereszt osztatú körablak, oromzatán pedig két nagyméretü, félköríves ablak kapott helyet. A bal oldalhomlokzaton a középső ablak kétszárnyú kapura támaszkodik.

Az előző templomot 1800-ban szentelték fel, és 1825-ben bővítették szentéllyel és toronnyal. ${ }^{124}$ 1944. december 9-én „este 5 órakor levegőbe repítették a templom tornyát $\mathrm{s}$ vele a tetőzet nagyobb részét" ${ }^{125}$ 1947-ben kaptak egy új telket templomépítés céljára, ${ }^{126}$ ahol 1948-ban fogtak hozzá az építkezéshez Domokos Ottó budapesti építész és Petrovics Gábor pestlőrinci mérnök tervei alapján. A fennmaradt képeslapon ${ }^{127} \mathrm{~T}$ alaprajzú, összetett tömegü épület látható. A nyeregtetős hajóhoz annak szentély felőli végén egy magasabb, nyeregtetős, a hajó bal oldalának két harmadához pedig 


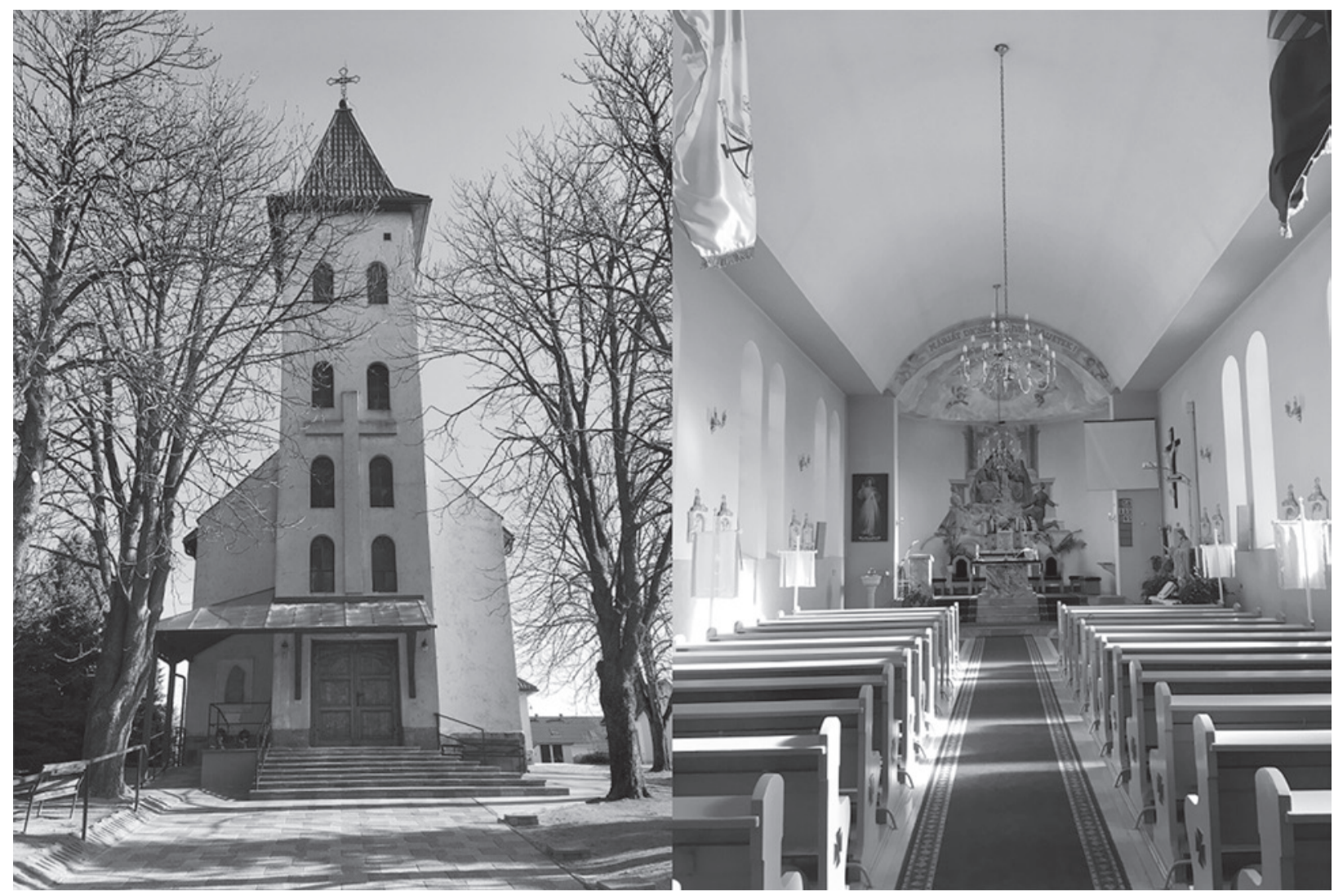

13. Inárcs, templom (fotó: Lantos Edit)

egy sokkal alacsonyabb lapos tetős épületrész, amihez pedig egy, a fóépületnél legalább kétszer magasabb torony csatlakozik. A főhomlokzaton a rézsűs kapu fölött kis körablak kapott helyet, a hajó oldalfalának felső szakaszán és a szentély hajó felé eső oromfalán keskeny ablaksor. A kép tanúsága szerint monumentális (hisz a környező házaknál háromszor magasabb - vagy igencsak elrajzolt) épület falai részben már álltak, amikor az építkezés 1954 decemberében félbemaradt. ${ }^{128}$ 1959-ben, Kovács István megbízott esperes plébános kinevezése után folytatták újra. Akkor azonban a község elrendelte a bontást. ${ }^{129}$ Felmerült ugyanannak az épületnek rövidebb és alacsonyabb kivitelü felépítése, a már elkészült szentély és oldalfal felhasználásával. 1960. augusztus elejére azonban eldőlt, hogy a korábbi épületkezdeményt le kell bontani, és egy új helyen kell építkezniük. Ehhez Árkay Bertalantól rendeltek terveket. ${ }^{130}$ Szeptemberben megkapták az engedélyt. 1960. október 4-én fogtak a munkához, 1961 folyamán felépült a templom, novemberben már kész volt a tető vasszerkezete. 1962 első felében szerelték fel a kazettás mennyezetet és rakták le a padló mozaiklapjait. ${ }^{131}$ Megáldására 1962. június 3-án került sor. ${ }^{132}$ 1963-ra lettek készen a külső és az altemplom belső vakolásával, és ablakaival. ${ }^{133}$
Az építéstörténet alapján az Árkay-hagyaték mindkét, Óplébánia elnevezésű tervének megtaláltuk a helyét. Ezek szerint a helyreállítás elnevezésű a Domokos-féle épület áttervezése lehetett. Ahhoz képest hiányzik a torony, és a bal oldali alacsony épületrész a teljes hosszon végigfut. ${ }^{134}$ Hiányzik a hajónál magasabb szentély-épületrész is. Helyette egy, a hajóval megegyező gerincmagasságú, pusztán bal oldali sekrestyével bővített szentélykiképzést látunk. A hajó széles félköríves, és a szentély két oldalán elhelyezett, keskeny félköríves ablakaival Árkay egy egyszerübb megoldáshoz nyúlt. A homlokzat magasabb elő-építménnyel való megoldása is eltér a Domokos-féle tervtől. A másik tervanyag pedig nagyobb részben a ma is álló épületé, ám nem teljesen. A főhomlokzat oromzata kevésbé magasodik fel, fő motívuma pedig nem a felső kettős, íves nyílás és a kereszttel tagolt körablak, hanem egy kisebb körablakkal tagolt keskeny, négyes vakárkád. A szentély bővítményei nem lapos tetősek, hiányzik a bal oldali bejárat, és a jobb oldali bővítmény két szélső fülkéje nélkülözi oszlopait és ablakait. A szentély oldalfalain három keskeny ablak és árkád helyett mindkettőből csak két szélesebb van. A kórus pedig két oszlopra támaszkodva egyenes vonalban köti össze a bejárat felőli két pilasztert. Ezenkívül nem egyezik több részletmeg- 


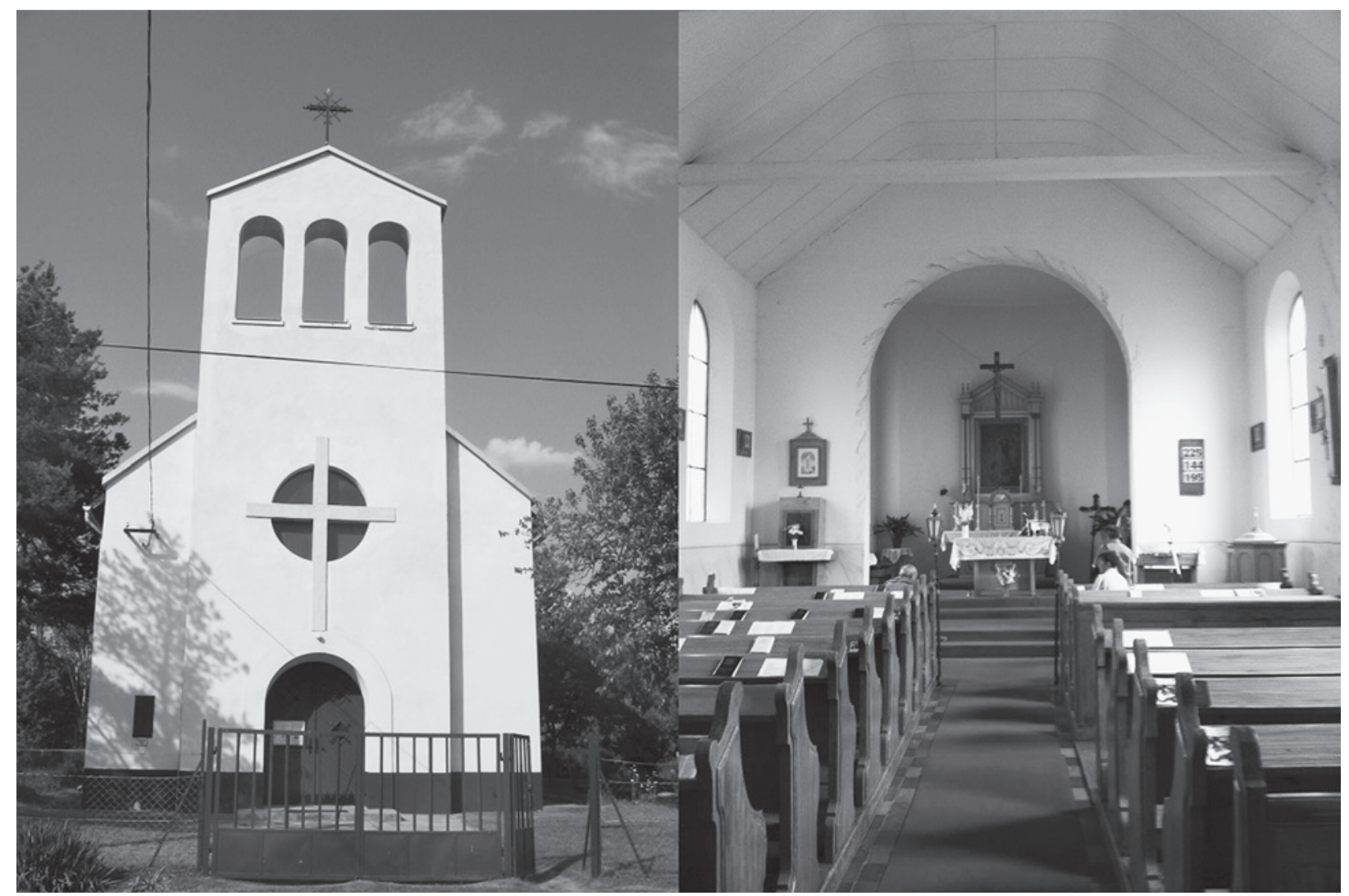

14. Móricgát, templom (fotó: Lantos Edit)

oldás sem: a bejárati kapu nem kovácsoltvas, hanem fa kapuzat, sarkára állított négyzet alakú ablakokkal. A hajónak a pilaszterek vonalában kötőgerendákkal tagolt síkmennyezete és a szentély egyszerü síklefedése helyett az egybefüggő mennyezet két rézsűs és egy középső vízszintes szakaszból áll, amit kazettákkal tagoltak. Az eredetileg tervezett, gömbön álló koszorús, kovácsoltvas kereszt helyére egy egyszerü, alumíniumból készült került.

\section{1-1965}

A pátrohai (Szabolcs-Szatmár-Bereg megye) templomterv ${ }^{135}$ tömegében, alaprajzában, sőt még az ablakok elosztásában is megegyezik a tiszalöki tervvel, ám itt a nyeregtető szögét ismétlő harangfalon az egyenes záródású kovácsoltvas kapu és előtető fölött kereszt tagolta körablak, afölött pedig egy - a kapunál is méretesebb - félköríves nyílás van. A pátrohai megvalósult templom ${ }^{136}$ tömegében a fenti tervet követi, csupán a sekrestye került a másik oldalra. Főhomlokzata oromfalas, a terven jelölt oromzat/pengefal hiányzik. Az oromfalig felnyúló, három, lépcsőzetes lemezből kialakított, félköríves nyílást a kovácsoltvas kapu fölötti előtető osztja két részre, a felső ablaknyi szakaszt pedig kereszt tagolja. Mellette egy-egy kisebb vakajtó, kettős keretezéssel. Itt a korábbi, malomból átalakított vályogépület összeomlása után kezdtek 1961-ben templomépítésbe. ${ }^{137} \mathrm{Az}$ építési engedélyt gyorsan megkapták, és az augusztusban megkezdett munka december 17-én be is fejeződhetett. ${ }^{138}$

A parádsasvári (Heves megye) templom terve ${ }^{139}$ T alaprajzú, kialakításában a szalkszentmártoni második, egyszerű tervet követi. Az a különbség, hogy a szentély mindkét oldalára került kiszolgáló helyiség, négy helyett három ablaka szögletes, és a fakapu fölötti körablak keresztosztása latin kereszt. 1962-ben az üveggyár egyetértésével, ${ }^{140}$ fuvar és társadalmi munka segítségével kezdődött meg az új templom felépítése. ${ }^{141}$ Az egyházközség „ebbe a tájegységbe illö, a hívek szükségeinek megfelelő kápolna"142 megtervezésével bízta meg Árkayt, akinek terve 1962. január 11-re datált. Az építkezés 1962. november 25-én fejeződött be. ${ }^{143}$

Tiszaeszlár (Szabolcs-Szatmár-Bereg megye) katolikus templomának téglány alakú hajójához a nyolcszög három oldalával záródó szentély és egy kisméretü négyzetes sekrestye tapad. A homlokzati torony felső szakasza minden oldalon keskeny, félköríves páros nyílásokkal áttört, alattuk a főhomlokzaton kereszt alakú ablak és egyenes záródású 


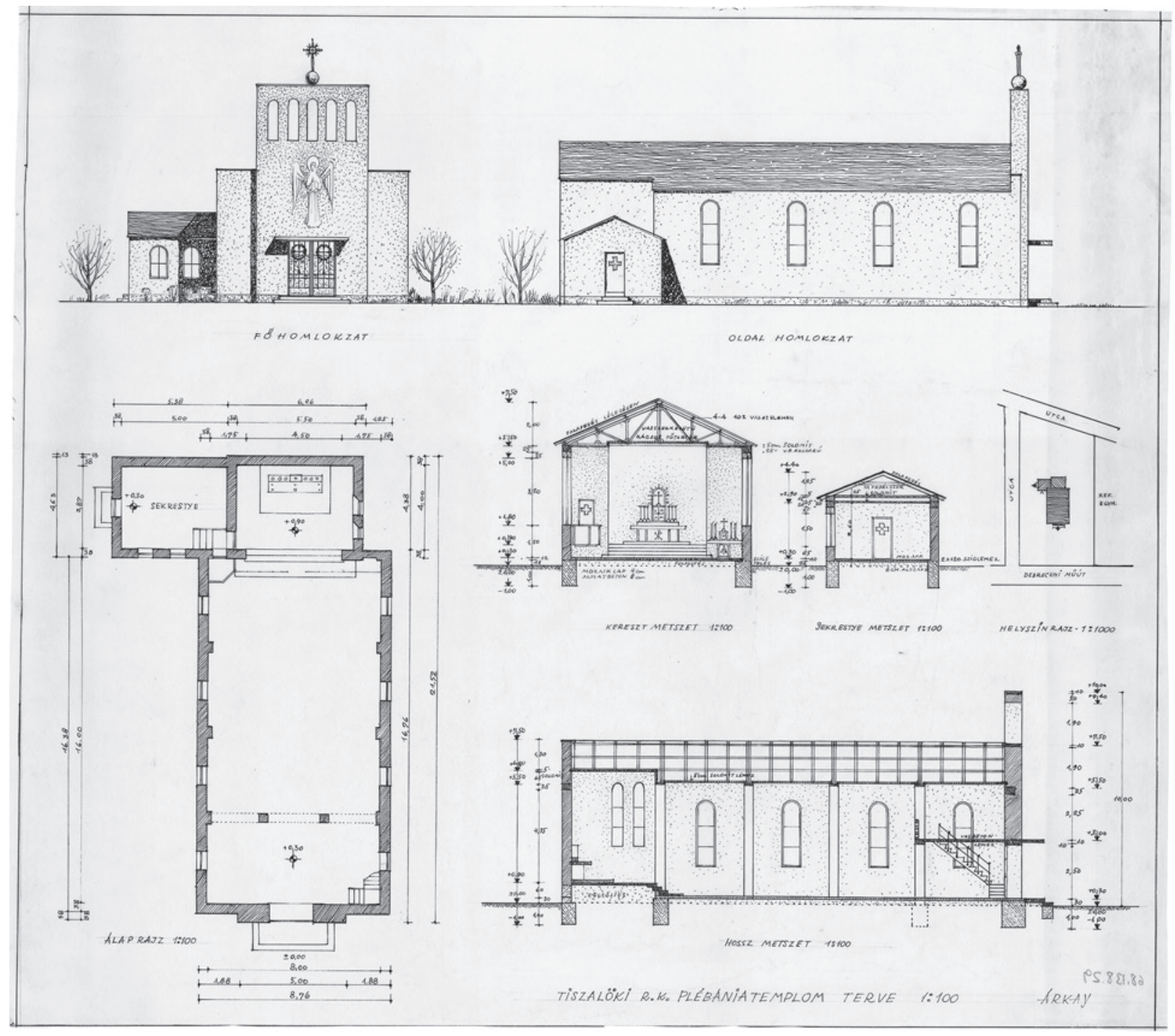

15. Árkay Bertalan: Tiszalöki r. k. plébániatemplom terve. Pausz, tus, $48 \times 54$ cm. BTM KM ÉGy ltsz.: 68.138.29.

félköríves, kovácsoltvas kapu található. Az oldalhomlokzaton a hajón öt keskeny, félköríves, a kóruson és szentélyen kettő ugyanilyen arányú ablak nyílik. Tiszaeszlárhoz tizenegy tervet köt ${ }^{144}$ az Építészeti Gyűjtemény. Az egyetlen aláírt példányon „Tiszaeszlári r. k. imaház helyreállítási terve" felirat szerepel. A méretezett és léptékes terven vakolt falazatú templom alap- és helyszínrajzát, fő- és oldalhomlokzatát, kereszt- és hosszmetszetét látjuk.

$\mathrm{Az}$ építéstörténetből tudható, hogy valójában itt nem helyreállításról volt szó, hanem ugyanúgy, mint Inárcs esetében, Árkaynak figyelembe kellett vennie az eredeti alapokat. A korábbi templom tornya ugyanis a háborúban robbant fel, maga alá temetve a teljes épületet. ${ }^{145}$ Többszöri próbálkozás után végül Brezanóczy Pál apostoli kormányzó is- mételt és nyomatékos közbelépésére 1963 márciusában kaptak építési engedélyt. ${ }^{146} 1964$. január 8-án Csékán Lajos lelkész arról számolt be, hogy a „templomépítés ügyét Árkay mérnök úr e napokban dűlőre vitte. Annak építését Szabó Lajos, ${ }^{147}$ tiszavasvári vállalkozóra bízta" ${ }^{148}$ 1964-ben kiderült, hogy a torony is együtt épülhet a templom többi részével. ${ }^{149}$ Árkay még húsvét előtt elkészíti ennek póttervét. ${ }^{150}$ Brezanóczy Pál 1965. augusztus 15-én konszekrálta a templomot. ${ }^{151}$ A levéltári források alapján egyértelmú Árkay tervezősége még akkor is, ha a tiszaeszlári egyházközség végül fel sem tüntette Árkay nevét a templom építéséről szóló márványtáblán. Ott ugyanis csak Szabó Lajos építész, Molnár Imre lakatos, Mann István kőfaragó és Asztalos Gyula asztalos szerepel. ${ }^{152}$ 
Kutatásunk jelenlegi állása szerint Árkay tervei alapján tizenhárom templom építése indult meg, amiből tizenkettő ma is áll. Árkay müjegyzéke még további hét helyszínt sorol fel az új templomok között: Jászdózsa, Pestszentimre, Polgár (torony), Kerecsend, Fényeslitke, Alag, Felsőgöd.

Jászdózsa és Felsőgöd egyházmegyei levéltári anyagában Árkay neve nem szerepel. ${ }^{153}$ A pestszentimrei templom és a polgári torony újjáépítés, ${ }^{154}$ a kerecsendi templomot pedig Márkus Béla tervezte, Árkay csak a tető terveit készítette. ${ }^{155}$

Fényeslitke templomába az Egri Főegyházmegyei Levéltár iratanyaga szerint Árkay az új oltárt tervezte 1965-ben. ${ }^{156}$

Alagon ${ }^{157}$ 1933-ban fogtak hozzá a templomépítéshez. Az év február 14-én mutatta be Árkay a terveit, amit a képviselőtestület megvitatott. Az elhangzó vélemények summázata az volt, hogy a "terv szokatlan, de hiszen valamikor a fóti templom $\mathrm{Ybl}$ Miklós által alkotott terve is forradalmi alkotás volt, szinte merész újítás. (...) Ne utánozzunk! A mai kor fia nem kezdhet elavultba, nem ragaszkodhat a régihez, mely nem felel meg az általános elszegényedésnek. Ez a terv szegényes, mégis müvésziesen nagyszerü."158 A háromhajós, szögletes szentélyzáródású templomhoz kétoldalt árkádsor csatlakozott, amit bal oldalt négyzetes torony szakított meg. A keskeny oldalhajók falain kör-, a föhajóén és a szentélyén keskeny félköríves ablakpárok nyílnak. A főhajónál rövidebb és jóval alacsonyabb mellékhajók, a szélfogó, a szentély és az árkádsor és a torony más-

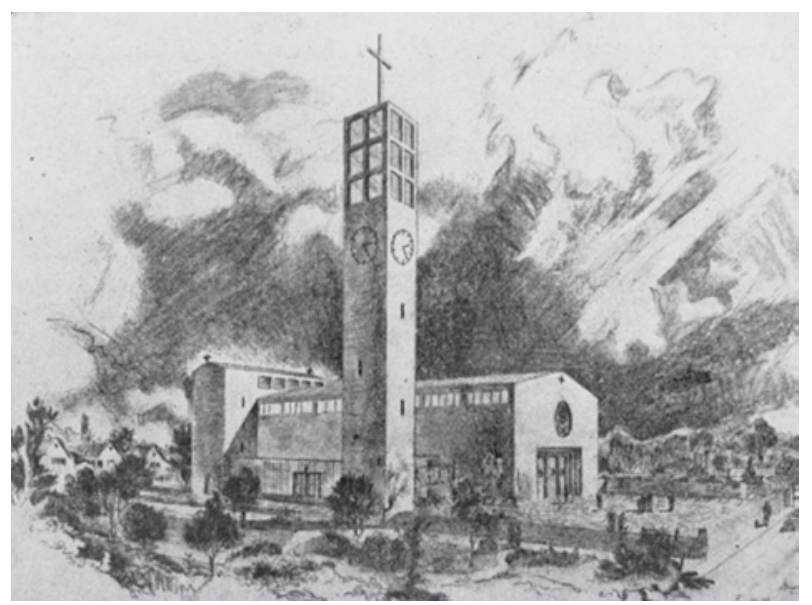

16. Domokos Ottó: Vecsési Szentkereszt templom. Képeslap VPKL VII. Gyüjtemények 3. B. V. Vecsés más magasságú, lapos tetős tömbjeiből szerkesztett épülettömeg egyenes mennyezetü hajót rejt. Főhomlokzatát a hármas íves bejárat fölött szoborfülkékkel körített kereszt, a hajó fölötti szakaszban pedig egyegy kisebb ablaknyílás tagolja. Bár a tervet elfogadták, 1936-ban végül mégis Fábián Gáspár tervei és vezetése szerint kezdték meg a templom építését. ${ }^{159}$

A hagyatékban még egy datált és egy stíluskritikai alapon erre az időszakra tehető templomterv van. ${ }^{160}$ A nyárásiként azonosított, 1958-ra keltezett keresztmetszet szentélynézete azonban nem egyezik a Nyárás feliratú, datálatlan engedélyezési terv ${ }^{161}$ szentélymegoldásával, így pontosabb azt állítani, hogy készült 1958-ban egy szentélykeresztmetszetet ábrázoló rajz, valamint egy Nyárás nevü helyszínre készült terv, ami kialakításában a tiszalöki tervhez hasonló, így minden bizonnyal 1945 utánra tehető. A helyzet sajátossága, hogy ezt a tervet eddig még nem sikerült településhez kötni. Nyáregyháza iratanyagában nem említik az 1957-es templomfelújítás kapcsán Árkayt, ${ }^{162}$ Nyársapát levéltári anyagában pedig ugyan szó van 1959-ben egy templomtervezésről, de a költségvetés és a tervek aláírója is Zsupon János budapesti okleveles mérnök. ${ }^{163}$

Lőrinci datálatlan kápolnaterve szintén a fent ismertetett engedélyezési tervek sorozatába illik, de itt is csak korábbi templomról, illetve kápolnáról tudunk. $^{164}$

Amint láttuk, Árkay müjegyzéke hét olyan helyszínt is felsorolt, ahol valójában nem épített új templomot, és kihagyott kettőt, ahol viszont igen, és a

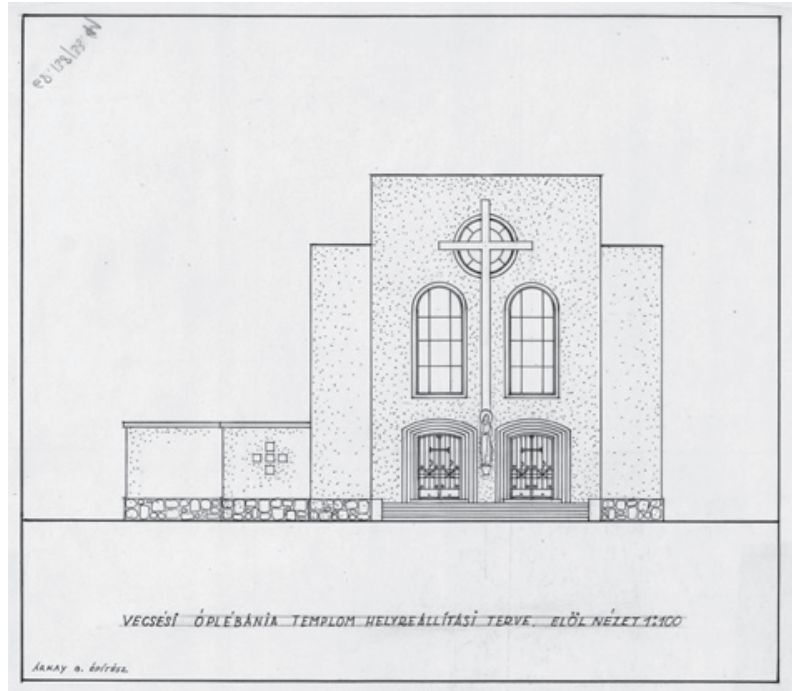

17. Árkay Bertalan: Vecsési r. k. óplébániai templom, helyreállítás. Föhomlokzat. Pausz, tus $31 \times 36 \mathrm{~cm}$. BTM KM ÉGy ltsz.: 68.138.33_11. 
datálásokban is rendre tévedett. A teljes listán mindössze Gerjen, Móricgát és Tiszaeszlár helynévhez írt olyan évszámot, amit a források is alátámasztottak. Nem hagyatkozhatunk a tervanyag adatolására sem. Azon kívül, hogy kétségeink támadtak a leltárkönyv azonosításaival kapcsolatban, magukon a terveken is több esetben találunk olyan feliratot, jelzetet, amit a levéltári források nem igazoltak. Egyelőre talány maradt a ceglédi, 1945. március 10. jelzetű alapozási tervnek és a soproni tervanyag 1950-1952. jelzetü terveinek ${ }^{165}$ elhelyezése. A források egybevetésének és vizsgálatának segítségével mégis sikerült tisztázni, hogy nem négy, öt, kilenc, tizenegy vagy tizenkilenc új templomot épített Árkay Bertalan 1945 után. Egy jó nevü építész tizenkét templomának, tizenhárom templomépítésének, illetve tizennégynél is több tervsorozatának jelen adatolása azonban azt mutatja, hogy az adott időszak és életmű feldolgozásához is nélkülözhetetlen az alapkutatás és a prekoncepciók nélküli forráskritika.

\section{Ékességek, avagy a tizenkét templom formai jegyei}

Míg Hort (1954) ${ }^{166}$ és Taksony (1958) ${ }^{167}$ Árkay Bertalan tervezte templomai formátumukban és kialakításukban is nagyobb szabásúak, a fent ismertetett templomok kisebb léptékűek. ${ }^{168}$ E templomok terveit és épületeit szemlélve szembetünőek bizonyos formai jegyek, részletmegoldások ismétlődései: a homlokzatkialakításoktól az ablak- és kapuformákon át az előtetőkig - sőt kilincsekig - számos ismerős alakzat köszön össze egymással. A továbbiakban ezek ismertetésére térek ki.

Térelrendezésük alapján a gerjeni három-, a kisbácsai kéthajós, a többi egyhajós elrendezésű. Szentélyformálásban terven leggyakoribb a szögletes alaprajzú, egyenes záródású, ${ }^{169}$ megvalósult épületben azonban a sokszögü záródás. ${ }^{170}$ Árkay templomainak ablakai legtöbb esetben félkörívesek, ritkábban egyesével, ám inkább párokban, vagy hármasával állnak, szélességük pedig igen gyakran fordítottan aránylik számukhoz. Több helyütt pilaszterekkel tagolja a hajó falait. ${ }^{171}$

A megépült templomok homlokzatkialakítása szempontjából három fő változat különíthető el: a homlokzati tornyos, az oromfalas és az oromzatos megoldás. Homlokzati tornyos ${ }^{172}$ templom épült Gerjen, Kömpöc, Inárcs, Tiszaeszlár és Ujtikos községekben. Bár a megvalósulás eltért, eredetileg a gerjenihez hasonló egy nagy nyílással tervezett volt Kömpöc és Újtikos tornya. Három templom oromfalas főhomlokzati kialakítású. A markánsan különböző megoldások közül a parádsasvári (amint a szalkszentmártoni második tervváltozat is) összes

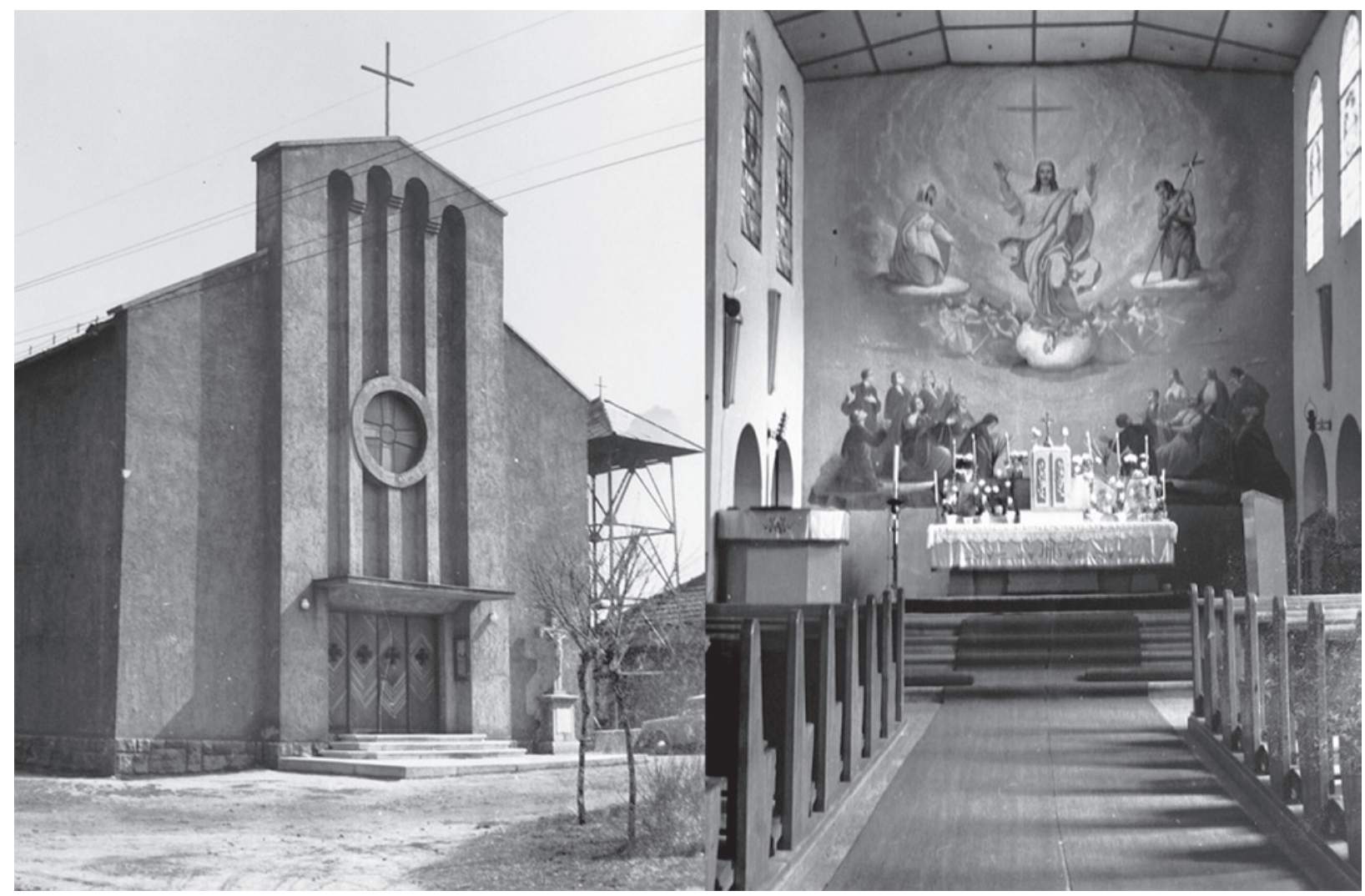

18. Vecsés - Óplébániai templom, fotó. VPKL VII. Gyüjtemények 3. B. V. Vecsés 
dísze csak egy kapu és egy körablak, a pátrohai három félkörívvel tagolt, míg a kisbácsai a kereszt szárai köré rendezett ablakokkal a legkevésbé historizáló és legeredetibb megoldású.

Harangfalas/oromzatos ${ }^{173}$ templomból a vecsési óplébánián, Móricgáton és Szalkszentmártonon kívül csak Hernádon épült még egy. E négy pengefalas homlokzat közül három a nyeregtető szögét követi, egy pedig egyenes záródású. A Vecsés-óplébániai egyedüliként vakárkádos, míg a hernádi egy, a móricgáti három, a szalkszentmártoni pedig öt félköríves nyílással áttört. A tervanyagban ez a fajta áttört megoldás másutt is megjelenik: a hernádihoz hasonló egynyílásos oromfal látható a pátrohai terven, kétnyílásos a Vecsés-óplébániai terven, és szalkszentmártonihoz hasonló megoldás jellemzi a nyárási és tiszalöki terveket is.

\section{(Excursus a szakirodalomról)}

A témánkat tárgyaló eddig egyetlen tudományos igénnyel fellépő Urbán-Vukoszávlyev szerzőpáros a "valóság - kompromisszumok szülte típusterv"-ként értelmezi a tiszalöki, nyárási, szalkszentmártoni, a két vecsési, pátrohai, móricgáti és újtikosi homlokzatkialakításokat, és kijelentik, hogy az „oromzati (harang)fal mintája” az ötvenes évek második felében keletkezett. ${ }^{174}$ Úgy gondolják, e sorban a csak tervként ismert tiszalökinek és nyárásinak kellett a legkorábbinak lenni, ${ }^{175}$ amit a szalkszentmártoni követ. A minta megszületésének datálásához felhasználják a két vecsési templomot is, és ennek során az Andrássy-telepi templom, de a Domokos Ottó tervei alapján elkezdett építkezés áttervezése is Árkay egyéni invenciójaként jelenik meg, amiben az olyan tények, mint az oromzat helyett homlokzati torony, vagy harangnyílás helyett vakárkádos oromfal megléte, illetve az Árkay által helyreállítási tervként történt megnevezés sem akadály. Gondolatmenetüknek több ponton is áldozatául esik az épületleírás. A szerintük a vecsési Szent Kereszt-templomhoz „közel hasonló megoldásokkal épült"176 hernádi templomnál ugyanis valójában csak az egyik oldali szentélybővítmény, az altemplom, illetve a mellékkápolna-gyóntatófülke épületrész hiányzik, illetve az teremtemplom, míg a vecsésinél a szentély és a hajó elkülönül. A hernádi főhomlokzatán nem vakárkád van körablakkal, hanem félköríves ablakok, illetve nyílás, az oldalhomlokzaton pedig az ablakok hármasával állnak, míg Vecsésen összesen három-három széles ablak van mindkét oldalon. De kétségtelenül megvan mindkét épületen az egyenes záródású

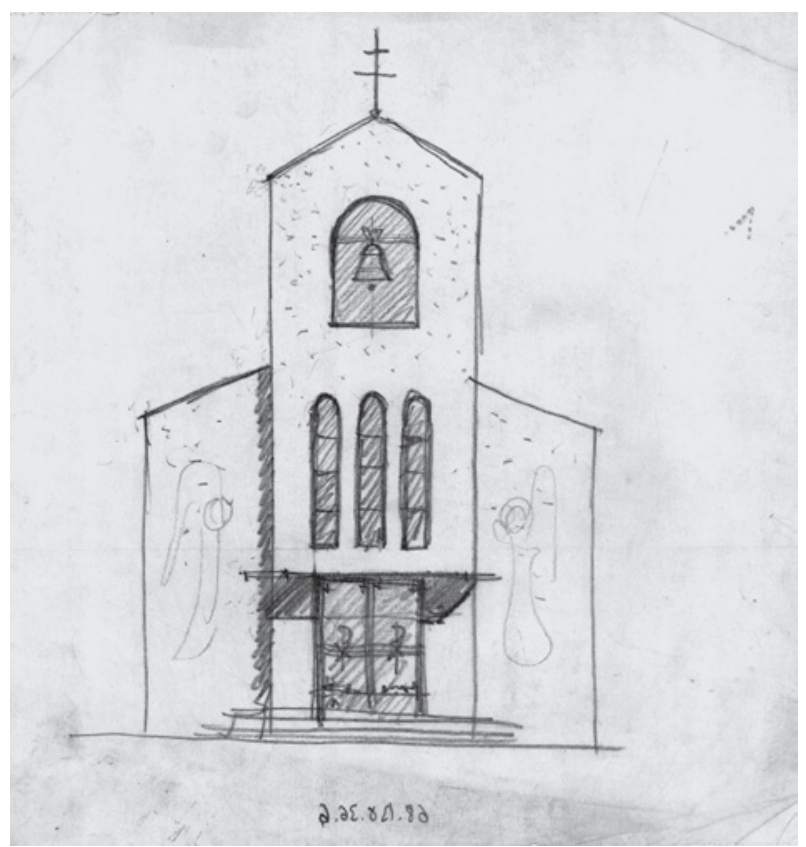

19. Árkay Bertalan: Tiszaeszlári templom [Hernádi-L. E.]. Homlokzat. Selyempapír, ceruza, $34 \times 32 \mathrm{~cm}$. BTM KM ÉGy ltsz.: 68.138.36_6.

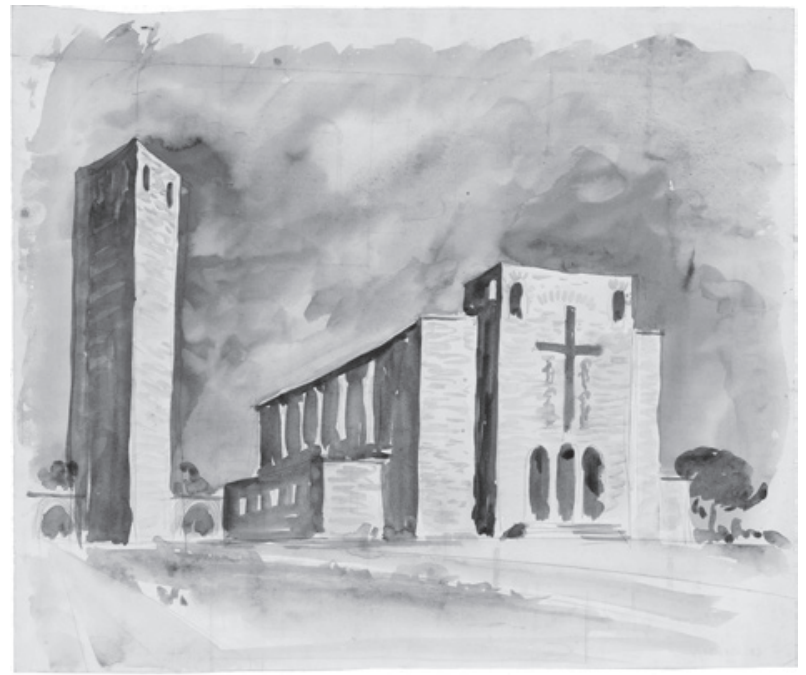

20. Árkay Bertalan: Alagi r. k. plébániatemplom terve. Távlati kép. Papír, akvarell, ceruza $38 \times 46 \mathrm{~cm}$. BTM KM ÉGy ltsz.: 68.138.38_4.

(itt kovácsoltvas, ott pedig fa-) kapu fölötti (egyik helyen ívesen metszett, a másikon téglány) előtető. Problémás, hogy szerintük Vecsésen a "torony szerepét a főhomlokzatból kiugró megemelt oromzati rész hivatott helyettesíteni hasonlatosan a taksonyi és a korábban látott falusi templomok példáihoz" ${ }_{177}$ mivel éppen Taksony a jó példa arra, hogy a felmagasodó középső homlokzatszakasz nem feltétlenül a torony kiváltását szolgálta, hiszen ott a templomépület és a leendő torony alapozása egy időben készült el. ${ }^{178} \mathrm{~A}$ kronológia szintén odavész 
a bizonyítás során: Vecsés Szent Kereszt-titulusú templomát - a maga 1960-ra keltezett tervanyagával - origóként állítják Hernád (terv: 1957, felszentelés: 1960) és Móricgát (terv: 1957, felszentelés: 1959) templomaihoz, úgyhogy ez utóbbihoz az 1961-es pátrohai jelenti az átvezetést. ${ }^{179}$ Az ideálterv megvalósulásaként tárgyalt kisbácsai templom is valójában éppen egy időben épült a többi példaként felhozottal, és az, hogy Árkay a méret redukálásával, de Szalkszentmártonnak is felajánlotta ennek tervváltozatát, bizonyítja, hogy szó sincs arról, hogy az „szinte csak a »fióknak « készült" ${ }^{180}$ volna. Összefoglalójukban megismétlik és tovább füzik a következtetéseket, miszerint „a taksonyi épület egy-egy eleme visszaköszön: a bejárati kapuzattal összefogott harangfalas képzés a legegyszerúbb minőséggel készült templomnak is Árkay-védjegye az '50-60-as évek fordulóján. Szalkszentmárton, Vecsés, Hernád és Móricgát redukált formálású teremtemplomainak ${ }^{181}$ szinte egyetlen »dísze « e formaképzési megoldás - mely alapvetően fel kívánja oldani a toronyépítés elleni politikai nyomást."182 Ezzel szemben Taksony főhomlokzati építménye legfeljebb annyiban rokonítható a fentiekkel, hogy magasabb, mint a hajó. Csakhogy itt nem egyetlen áttört vagy vakárkádokkal tagolt pengefalról, hanem külön épületrészről van szó. 2016-os másik cikkükben „,a nagy modern templomépítész mester, Árkay Bertalan" művei közül ismét a két vecsési és a hernádi templomot emelik ki. „Vecsés Szűz Mária Szeplőtelen Szíve (1948-1958), Vecsés Szent Kereszt felmagasztalása (1960-1962) és Hernád Szentlélek (1961) római katolikus temploma anyagi és a (későbbiekben egyre jelentősebb) politikai viszontagságok ${ }^{183}$ miatt egyértelműen kompromisszumot felvállalva - egy Arkayéval jól azonosítható építészeti törekvést, a homlokzati harangfal építészeti invencióját példázzák" ${ }^{184}$ Ehhez képest a három megnevezett templomból csak kettő oromzatos, és csak a hernádién van olyan nyílás, ami alkalmas lehet harang elhelyezésére. Összegzésük szerint az Árkay-féle „harangfalas megoldás »típusterve« végül nem vált elfogadottá széles körben, nem terjedt el a korszakban. Ennek oka - megítélésünk szerint - nem a felmutatott alternatíva életképességében (ha tornyot nem szabad építeni, ${ }^{185}$ akkor a monumentalitást ezen egyszerű formai eszközzel is el lehet érni), hanem a hazai tradicionális templomképtôl való eltérés, nemkülönben pedig az az építészeti stílusváltás eredményezi (sic!), mely a nemzetközi építészeti irányzatokra újra nyitott hazai építészetben már a stíluspluralizmus jegyében új utakat keres, merőben megváltoztatni kívánva a templomformálást" ${ }^{186} \mathrm{Az}$ állítás azonban sajnos több sebből is vérzik. Egyrészt míg harangfalas templomból
(Hernád, Móricgát, Szalkszentmárton) csupán három, addig homlokzati tornyosból csak Árkay ötöt épített. Másrészt ez a fajta harangfal nem tekinthetô Árkay egyéni formaképzésének, lévén gyakori eleme a mediterráneum falusi templomainak is. Ráadásul azt, hogy még eredeti ötlet szinten sem Árkayé ez a fajta kialakítás, jól mutatja, hogy Csaba László ugyanezt a nyílással áttört homlokzati pengefalat alkalmazza 1959-es, Cserépváralja templomához készült tervén, ${ }^{187}$ formai eredetiségben, anyaghasználatban jócskán felülmúlva idősebb kortársát. Ahogyan Cserépváralja temploma a legjobb bizonyíték arra is, hogy a harangfal semmiképpen sem egy stílushoz kötött építészeti elem.

Es természetesen fogalmi nonszensz típustervrő $1^{188}$ beszélni. Az ugyanis „az igények, feltételek, a rendelkezésre álló anyagi-technikai eszközök tudományos felmérése és összegzése útján kiérlelt és optimális megoldást rögzítő terv" ${ }^{189}$ mely tömeges gyártásra, telepítésre alkalmas. De Árkay esetében szó sincs ilyenről. Valójában még a típus épületszekció sem áll meg, hiszen annak feltétele lenne a méretegyezés. Az Urbán-Vukoszávlyev szerzőpáros szerinti „harangfalas megoldás »típusterv « szintű feltünése" azonban (amit a tiszalöki és nyárási templomterveken, illetve a megépült szalkszentmártoni homlokzaton érnek tetten ${ }^{190}$ ), a tervek tanúsága szerint eltérő méretűek. ${ }^{191}$

A tizenkét épület és a számos tervváltozat leírása is megerősíti, hogy nincs szó típustervekről, hiszen Árkay egyetlenegyszer sem adta oda ugyanazt a tervet két megrendelőnek. Ám az is látszik, hogy voltak bizonyos formai megoldások, amiket előszeretettel alkalmazott. Ezek sorra vételével nemcsak az Árkayra jellemző építészeti jegyeket, hanem - reményeim szerint - munkamódszerét is megismerhetjük.

\section{Árkay eszközkészlete, munkamódszere}

Az egyik legszembetűnőbb a félköríves ablakok, nyílások kedvelése, amik a legtöbb Árkay- épületen ott vannak. A nagyméretü, félköríves áttöréseket megtaláljuk tornyokon (Gerjen, Móricgát képeslapterve, Kömpöc, Újtikos terve), illetve harangfalakon (Hernád, Pátroha terve), a hármasával, illetve ötösével elhelyezett keskeny nyílásokat (Móricgát, Szalkszentmárton, Tiszalök és Nyárás terve), ablakokat a főhomlokzaton (Hernád, Szalkszentmárton). A hagyaték nagy számban őriz variációkat erre a témára. Egyenes és nyeregtetős harangfalakon szélesebb és keskenyebb, önmagukban álló, vagy sorokat, oszlopokat alkotó változat egyaránt megjelenik. ${ }^{192}$ 
Árkay templomainak főhomlokzati motívumai közül legegyedibbnek a kereszt szárai köré rendezett ablak/fülke kialakítás tűnik (Kisbácsa, Inárcs, Szalkszentmárton első terve). A hagyaték tanúsága szerint ez sem előzmény nélküli: az 1933-as alagi, az 1934-es Soroksári úti templom tervén, a Balatonlelle templomához készült 1942-es vázlaton és számos datálatlan vázlatrajzon is láthatjuk, ${ }^{193} \mathrm{de} \mathrm{ez}$ jelenik meg az 1941-es Egyházművészeti Kiállítás Árkay tervezte templombelsőjében az oltár mögötti falon is. ${ }^{194}$

Gerjen homlokzatának rózsaablaka a három félköríves nyílással ${ }^{195}$ ismerősnek tünhet a soproni templomként azonosított távlati rajzon is, ahogyan a Balatonlelléhez kötött rajzok közt is találunk hármas árkádos bejáratot. ${ }^{196}$ Nagy különbség azonban, hogy Gerjenben az ívek egy nyitott szélfogóba nyílnak, míg a másik két épületnél a rajzok a legtöbb esetben egyértelmúen kapukat jeleznek, melyek mögött így egy zárt előtérbe jutunk. ${ }^{197}$ Különbséget kell tenni a homlokzat síkjában megnyitott hármas ív és a homlokzat elé épített íves árkádos szélfogó közt is. Míg előbbivel Ârkay előszeretettel kísérletezik rajzaiban, utóbbi jóval kevesebbszer ${ }^{198}$ jelenik meg, s akkor is csak mint egy összetett tömegü épület egyetlen eleme. Felépítve pedig egy helyen sem használja. ${ }^{199}$

A pátrohai templom megvalósult homlokzatának nagyméretü, kereszttel tagolt félköríves, széles keretezésű (bélletes kapukat idéző) ablaka, alatta az egyenes záródású kapuval ${ }^{200}$ a balatonlellei bejárati megoldás kicsiben. A latinkereszttel osztott körablak pedig, ami Móricgát, Parádsasvár, Újtikos, Pátroha vagy Vecsés - Óplébánia tervén is megjelenik, feltünik a csornai tervpályázatra és a balatonlellei templomhoz készült vázlatokon, illetve több vázlatrajzon is. ${ }^{201}$

Ugyanazoknak az akár 20-25 évvel azelőtti motívumoknak a kedvelése, újrázása lehet a kreatív elme egyazon alakzatnak változataiban, önmagában és az egészhez viszonyított arányaiban, illetve anyagában való kidolgozása is. De vannak olyan ismétlődések, amik mögött praktikus okok sejthetők.

Ezek közé tartozik a fentebb már említett kóruskorlát mutatós megoldása, és a görögkereszt alakú ablakokkal áttört fakapu is, ami Gerjenben, Kisbácsán, Parádsasvár templomtervén, a ceglédi gyóntatószék rajzán és több korábbi terven ${ }^{202}$ is megjelenik. A hagyatékban a balatonlellei és a mohácsi Fogadalmi templom ajtóihoz készült részletes, méretezett rajz ${ }^{203}$ többszöri felhasználásának ugyanúgy gyakorlati okai lehettek (a tetszetős épületrészekhez készen álltak az azokat megmunkáló mestereket eligazító rajzok is), mint az azokon lévő vasalatok (kilincsek, zárpajzsok, ajtólemezek) is- métlődéseinek. Nemcsak Móricgát és Gerjen templomkapuinak szív kivágású kapulemezei rímelnek egymásra, de halat formázó kilincseiknek egyszerủbb kialakítású társa ott van a hernádi és a horti kapun is. Ám nemcsak a kilincsek, hanem ezek a kovácsoltvas kapuk is - a taksonyihoz hasonlóan hosszú sima, rövidebb, keresztben végződő csavartpálcáikkal, szemmagasságban lévő, babérkoszorús latinkereszt-motívumaikkal, szegecses (Hort), illetve hajó-motívumos (Hernád, Szalkszentmárton, Taksony) kapulemezeikkel - a váci székesegyház altemplomának bejáratán jelennek meg először. ${ }^{204}$ A terveket Árkay készítette, de magán a váci kapun látható a mesterjelzés is: Kedvek Béla épületmúlakatos, aki a horti és a kömpöci építéstörténetben is felbukkan mint a kapu, a toronykeresztek vagy a szentélyrács készítője. ${ }^{205}$ Egy jól eltalált, másutt már sikeresen alkalmazott kapu (vagy egy részletének) újbóli felhasználását (az egyházközség anyagi lehetôségeihez alkalmazkodó cizelláltságban) és egy megbízható minőségben dolgozó, bejáratott mester többszöri megbízását látjuk itt.

\section{Okok}

Az épület és részleteinek, formai és technikai megoldásainak ismétlődései mögött sejtettük már a „variációk ugyanazon témákra” kreativitását, az anyagi lehetőségek behatároltságát, illetve kipróbált mesterek alkalmazását. Ahogyan ezen okok nem zárják ki egymást, úgy lehetséges mindezek mögött további indítékok keresése.

Ârkay az Építészeti Múzeumban őrzött önéletrajzai ${ }^{206}$ alapján 1949-től a Fővárosi Tervező Intézetnél és a Városrendezési Intézetnél, 1959-től pedig a Magyar Beruházási Banknál dolgozott mint fömérnök. A kettő közti időszakra (évszámok nélkül) megjelöli az Ipari Tervező Intézetet, a KÖZTI-t és a Bányászati Tervező Intézetet. ${ }^{207}$ 1962-től Az Ybl Tervező Szövetkezet elnöke (másutt: Országos Takarékpénztár főmérnökségén és), ${ }^{208}$ 1967-től a Távközlési Kutató Intézetben dolgozik. ${ }^{209}$

Életrajzaiban 1945 utáni templomépítéseiről nem ír, de egy belügyminisztériumi jelentés ${ }^{210}$ és a váci egyházmegyei levéltári anyagban több levél is az egyházmegye „építészeti szakértője”-ként ${ }^{211} \mathrm{em}$ líti. Ilyen minőségében pedig nemcsak a fent ismertetett munkákat végezte el, hanem egyéb tervezői, szakértői tevékenységeket is. Árkay 1958-as, a Váci Egyházmegyei Hatóságnak írt levelében nemcsak az inárcsi és a hernádi templomépítkezések aktuális állapotáról számol be, hanem arról is, hogy miként áll a pestszentlörinci felrobbantott torony- 
sisak új (vas)szerkezetének tervezésével, és hogy a pestszentimrei „felrobbantott templom befedésének tervezése folyamatban van". Ahogy Jászkarajenő temploma külső téglaburkolatának kijavítása is, Taksonyban pedig a "templom falai állanak az összes belső vasbeton szerkezettel együtt, csak a kupola betonozása maradt tavaszra". ${ }^{212}$ Hogy a különféle javítási megbízások általánosak voltak, az is mutatja, hogy a kömpöci templom építése kapcsán megismert építészre bízták 1958-ban a kiskunmajsai templom külső tatarozását is. ${ }^{213}$

Legyen szó tetőszerkezet tervezéséről (Maklár) vagy javításáról, oltár- vagy templomtervezésről, historizáló („Szent Anna-plébániatemplom főoltára" feliratú terv) ${ }^{214}$ vagy kortárs stílben (Kömpöc, Hernád, Fényeslitke), ${ }^{215}$ homlokzattervezésről müemléki elvárásoknak megfelelve (Polgár) vagy a templom eredeti tervezőjének munkáját folytatva (Vecsés Andrássy-telep), padokról, falikarról ${ }^{216}$ vagy mécstartókról, Árkay tette a dolgát. Talán nem is véletlen, hogy a tervezéssel, építéssel kapcsolatos levelezések visszatérő momentuma Árkay leterheltsége. ${ }^{217}$

\section{Kérdések és konklúzió}

Hangozzanak bár rettentő prózaian a fenti érvek, nem lehet tudomáson kívül hagyni azt az egyszerü tényt, amit a kronológia mutat: miközben 1957ben állami vállalatnál van fóállásban, már folyt a (nagyszabású) taksonyi templom alapozása és építése. Ugyanekkor rendeltek tervet Móricgát, Szalkszentmárton és Inárcs templomaihoz is. ${ }^{218} 1958$-ban Újtikos és Hernád tervezése, Szalkszentmárton tervváltozatai, építése mellett ott a vecsési Andrássy-telepi templom befejezése, és (a számos felújítási aprómunka mellett) folyik már a kisbácsai templom építése is. Ebben az évben vett részt egy párizsi kiállításon is, ahol díjat nyert. ${ }^{219} 1959$-ben a folytatódó építkezések (Kerecsend, Polgár, Inárcs, Újtikos építkezései, Kiskunmajsa felújítási munkái, Tiszalök tervei) mellett dolgozott a héhalmi műemléktemplom bővítési tervein is. ${ }^{220} \mathrm{~A}$ Beruházási Bank megbízásából pedig elkészítette a Fillér u. $49 .{ }^{221}$ bérház tervanyagát. Mindezek mellett talán érthetővé válik a fenti - „fusiban” készült - tervek és épületanyag „ékességei"-nek megannyi hasonló megoldása.

Lehet - és nyilvánvalóan szükséges is - a kreatív elme szárnyalása, vagy a tervezés szellemi folyama- ta, sőt a szakralitás ideális térbeli kifejeződése felől megközelíteni ezt a terv- és épületanyagot is. Ám a formai ismétlődések meglétével lehetetlen nem számolni.

Árkay életművének számomra releváns kérdése nem az, hogy Árkay Aladár „kiválóan tehetséges fia, Bertalan"222 a Győr-gyárvárosi templom, de különösen a városmajori templom formabontó merészsége után miért nem volt nagyobb hatású? ${ }^{223}$ Szándékoltan a gyakorlatias, a hétköznapi tervezői praxis felől közelítve meg az Árkay-életműnek ezt a szakaszát, azt remélem, hogy új szempontok hozhatók az œuvre megismeréséhez is.

Mivel azonban szakmai szemmel megkerülhetetlen az épületanyag értékelése, megalapozott az a kérdés, hogy elnézőeknek kell-e lennünk ezekkel az épületekkel, csak azért, mert alkotójuk 33 évesen beírta magát az építészettörténetbe? Láthatóan tovatünt a "fiú pazarló ifjúkora", ami az apa, Árkay Aladár "tapasztalatokon érlelődött bölcsessége" mellett 1930-ban „a magyar glóbuszon merőben előd nélkül áll és újat teremtett". ${ }^{224}$ Az 1945 előtti és utáni színvonal eltérése mögött sejthetjük a városmajori templomot ért támadásokat, és a sikertelen pályázatokat. ${ }^{225} \mathrm{~A}$ II. világháború után épült kisebb templomai, bár egyenként jó arányúak, tömegük és felületeik korrektek és a mindenkori használatot kiszolgálják, összességükben kevés tervezői invenciót mutatnak. Az egyediség helyetti rutinmegoldások pedig vagy ezt a kudarcok szülte kiábrándultságot jelzik, vagy hinnünk kell az Árkayt tárgyaló szakirodalom építészünk tehetségéről szóló állításainak. Gábor Eszter Árkay Bertalan villáiról azt írja, hogy „jól beilleszkednek a korszak szolid átlagába, sok újdonságot nem tartalmaznak, s vajmi kevés rokonságot mutatnak a városmajori templommal." ${ }^{226}$ Csáki Tamás pedig így fogalmaz: „Árkay nem rendelkezett olyan megújulási képességgel, mint a hozzá hasonlóan középutas építészetet művelő, a mindenkori igényekhez rugalmasan alkalmazkodó Kozma Lajos (...) vagy Rimanóczy Gyula (...). Árkay nem volt képes az ő bravúrjukra, arra, hogy építészetét újra és újra magas színvonalú alkotásokat létrehozva újítsa meg, formálja át, és mindeközben annak sajátos, egyéni karakterét is megőrizze."227

A horti és taksonyi templomok 2016-os feldolgozása után az itt tárgyalt kisebb templomokon és terveiken át (továbbá egy, az eddig még ismeretlen Árkay-anyagot bemutató következő dolgozatom után) célom az életmü egészének értékelése és a lehetséges konklúzió levonása. 


\section{JEGYZETEK}

$1 \mathrm{Az}$ Árkay Bertalan életművét feldolgozó háromrészes tanulmánysorozat megírását (melynek a Lantos 2016b után ez a második darabja) a Nemzeti Kulturális Alap Építőművészeti Kuratóriuma támogatta. A harmadik közlemény: Lantos Edit: A Salzburgi vázlat és a csonkolt téglatest. Két esettanulmány Árkay Bertalan (19011970) és Csaba László (1924-1995) életművéből. Ars Hungarica XLIII. 2017:2., 215-233.

2 VPKL AP Kakucs 3592/1957. Vincze Dezső plébános levelei (isz.n.)

3 Az épületek számáról 1.: Lantos 2009, 223.

4 Írásom a leadás előtt álló, A római katolikus templomépitészet Magyarországon, 1945-1970 címü PhDdolgozatom Árkay fejezet-részletének egy rövidített verziója.

5 Vákár 1982, 61; Rév 1987, 39-41; Cséfalvay 1988, 461462; Farkas 1991, 2; Lővei 2000, 88; Prakfalvi 2002, 269-270 (ugyanez: Prakfalvi 2004, 497); Kovács 2010, 18. Összefoglalásukat 1.: Lantos 2016b 319-320.

6 Cséfalvay 1988, 462. Kettőt Vecsésről, továbbá: Móricgát, Szalkszentmárton és Győr-Kisbácsa.

7 Urbán-Vukoszávlyev 2016, 13. Felépült: GyőrKisbácsa, Gerjen, Vecsés - Szűz Mária Szeplőtelen Szíve, Vecsés - Szent Kereszt Felmagasztalása, Hernád, Szalkszentmárton, Móricgát, Parádsasvár, Pátroha, Tiszaeszlár, Újtikos. Csak tervben maradt: Pécel, Cegléd, Tiszalök, Nyárás. Később említik Lőrinci tervét (33).

8 Vukoszávlyev-Urbán 2016, 249. Gerjen (288-289), Vecsés - Szűz Mária, Vecsés - Szent Kereszt, Hernád, Szalkszentmárton, Móricgát, Parádsasvár, Pátroha, Tiszaeszlár, Újtikos (307), Győr-Kisbácsa (308).

9 Pusztai 1972, 61. szerint az öt új: Hort, Gerjen, Cegléd, Taksony, Győr-Kisbácsa, az újjáépítések: Váci székesegyház, Polgár. Ugyanakkor megjegyzi, hogy „ezen kívül több kisebb templomot épített". Szekeres-Virág 1982, Tölgyes 1999 és Winkler-Domján 2010 csak a Pusztai által felsoroltakat említi, Barla-Szabó 1992 viszont csak kettőt (Győr-Kisbácsa, Taksony).

10 ÉM ÁB D (é. n., a jegyzék legkésőbbi megadott dátuma: 1964). A teljes lista 27 tételből áll, amin külön szerepelnek a városmajori és a balatonlellei templomok és azok tornyai (1. és 26., illetve 4. és 27. sorszámmal), de itt sorolja fel a Római Egyházművészeti Kiállítás templomát (3) és a váci székesegyház altemplomát (8) is. Ezen a listán is szerepel természetesen Hort (2) és Taksony (21) temploma. Ezeken felül pedig: Cegléd, Gerjen, GyőrKisbácsa, Hernád, Móricgát, Vecsés, Újtikos, Jászdózsa, Tiszaeszlár, Pestszentimre, Fényeslitke, Kerecsend, Szalkszentmárton, Pátroha, Inárcs, Alag, Felsőgöd.

$11 \mathrm{Az}$ Építészeti Gyüjtemény leltárkönyvei alapján 1968. június 13-án vették meg a teljes hagyatékot. A tervrajzok túlnyomórészt feliratozottak voltak, de a nagyszámú vázlatot nem Árkay azonosította be. (Branczik Márta, az Építészeti Gyűjtemény vezetőjének szíves közlése.) Emiatt csak az egyértelmüen azonosítottakra vagy azonosíthatóakra koncentrálok.

12 A nyolc új építésű templomterv: Cegléd, Gerjen, Kisbácsa, Nyárás, Parádsasvár, Tiszaeszlár, Vecsés Óplébánia és Vecsés. Itt sem számoltam bele az 1945 előtt megkezdett balatonlelleit (BTM KM ÉGy 68.138.31_13$14,22)$, és a tervanyag említette héhalmi templom bő- vítését (68.138.34_1-1-3, 5). Nem számolok a péceli (68.138.30_5) anyaggal, mert a tervek felirat és jelzet nélküliek, illetve Pécel Historia Domusa alapján 1945 után csak felújításról, illetve, bővítésről lehetett szó. HD Pécel 1944. év http://pecel.vaciegyhazmegye.hu/hd-1944-ev/ (Utolsó megtekintés: 2017.06.07.) Az egyházmegye történeti földrajza szintén nem említ tervpályázatot vagy 1945 utáni új építkezést. Varga 1997, 298-299. A soproni tervek (68.138.45_27, 30, 44) sem tartoznak már tárgyunkhoz, mert egy helyszínrajz (68.138.45_39) alapján úgy tünik, hogy a tervanyag a Szent István-templom tervpályázatára készült, ami 1938-ban volt, és ahová Árkayt, Rimanóczy Gyulát és Körmendy Nándort hívták meg. A Körmendy Nándor tervei szerinti építkezés 1940-ben indult meg és 1943-ban szentelték fel a templomot. Reisner 2013, 11, 14. Az 1950-1952-re datált "Sopron"-feliratos tervek valószínüleg ezeknek a korábbi terveknek a továbbgondolásai. Bár az Árkay-anyagban vannak, nem vehetjük számításba a polgári és szentkirályi üvegablakok fotóit sem (69.195.17_1-2 és 69.195.18_1-4), mert nincsenek szignálva és alkotóhoz kötve. Természetesen a tápiószentmártoni templomberendezés (68.141.3_11-12.) és a váci székesegyház kriptájának átalakítási tervei sem új építések. Ez utóbbi megnevezése „átalakítási terv”, amihez a felmérési rajzokat Dr. Lux Géza készítette 1943-ban, a feliratok és a jelzet alapján 1948-1949-ben dolgozott rajta Árkay. BTM KM ÉGy 68.138.28_1-2. és 4. (1943), 68.138.28_5. (1948), 68.138.28_3. (1949). Az Állami Gyermekmenhely kápolnájának terve sem önálló épület. 68.96.1-2. (1947).

13 Árkay műjegyzéke 1948-ra datálja az épületet, Urbán-Vukoszávlyev pedig csak tervanyagként ismeri. Urbán-Vukoszávlyev 2016, 13, 18, 38.

14 BTM KM ÉGy 68.138.23_1-29: 68.138.23_5. (1945. III. 10.), 68.138.23_2_1-2, 68.138.23_4_2, 68.138.23_7-8, 11, 25. (1947), 68.138.23_6. (1948), 68.138.23_28. (1949), 68.138.23_1_1-2, 68.138.23_3_1-2, 68.138.23_4_1 68.138.23_9-10, 68-138.23_12-24, 26-27, 29. (é. n.)

15 BTM KM ÉGy 68.138.23_1_2, 2_1, 2_2,3_2, 4_2, 5-6. 16 Egyszerü homlokzatok: BTM KM ÉGy 68.138.23_16, 22; háromszakaszos homlokzatok: $68.138 .23 \_8,12,15,18$, 23, 25; pilon: 68.138.23_21, 25; páros tornyok: 68.138.23_3_1, 4_1, 13-14, 17, 19-20, 24, 26-27, 29.

17 BTM KM ÉGy 68.138.23_3_2. (alaprajz), 27, 29.

18 Zsédely 2008, 62.

19 VPKL AP Cegléd 1102/47. Dr. Taraba József plébános levele (170/1947).

20 VPKL AP Cegléd Új plébánia 4546/47, dr. Tóth Tibor plébános levele (120/1947) és 2663/47. Tévesen állítja tehát a későbbi plébános, Zsédely Gyula a Historia Domusbeli visszaemlékezésében - és feltehetőleg ez alapján Varga -, hogy a telekért kellett a 10000 Ft-ot kifizetni. Zsédely 2008, 65. és Varga 1997, 72.

21 VPKL AP Cegléd 4546/47. iratcsomó. Idézetek: dr. Tóth Tibor levele 120/1947 és Dercsényi levele.

22 VPKL AP Cegléd Újplébánia 376/48.

23 VPKL AP Cegléd Újplébánia 2692/48.

24 VPKL AP Cegléd Újplébánia 2692/48. Tóth levele 103/1948. A képeslap a BTM KM ÉGy 68.138.23_12. vázlat kidolgozott verziója.

25 VPKL AP Cegléd Újplébánia 4/49. Tóth 1949. 01. 24-i levele és 5522/49. Tóth 1949. 11. 22-i levele 185/1949. 
A tölgyfalapokból készülő gyóntatószéket id. Sárik Ede múbútorasztalos készítette volna. A hagyatékban berendezésként azonosított terv (68.138.23_28. jelzete: 1949. XI. 15.) gyóntatószéket ábrázol.

26 Varga 1997, 72-73; Pusztai 1972, 61; Szekeres-Virág 1982, 149; Tölgyes 1999, 78; Winkler-Domján 2010, 142 tévesen datálja 1946-ra.

27 Összes terv: BTM KM ÉGy VII/2. 68.138.26_1-19, VIII/6. 68.138.26_1-8. Datált alaprajz, hossz- és keresztmetszetek, és homlokzatok: VII/2. 68.138.26_1, 5-8. (1948. IV. 11.); alaprajz, hossz- és keresztmetszetek: VIII/6. 68.138.26_1, 68.138.24_6-8 (1948. VIII.24.); homlokzatok és metszet a szentélyen át: VIII/6. 68.138.26_2-3, 68.138.24_35. (1948. X. 15.); rózsaablak-terv: VII/2. 68.138.26_16. (1948. XII.); Oltártervek: 68.138.26_11-12. (é. n.) Az utóbbi valósult meg.

28 BTM KM ÉGy VII/2. 68.138.26_9-10, VII/9. 1tsz.n. 4. ZM-SZK ltsz.: 90055

$29 \mathrm{Az}$ iratok „a falu minden pontjáról jól megközelíthető" területről írnak (PEL 3497/1947. Püspök Pál levele 348/1947), így megalapozatlannak tünik a telek elhelyezkedésébe belelátni a református többség és a katolikus kisebbség erőviszonyait. Miután pedig nem igaz a "telepítés háttérbe vonuló magatartása”, az „a formálás visszafogottságán" sem tükröződhet (Urbán-Vukoszávlyev 2016, 21). Ahogyan érdekes elképzelés a háromhajós, összetett tömegü, $30 \times 15 \times 9$ m méretü templomot falusi templom mintájára készült épületnek tekinteni. (Uo. 13. és 38.)

30 PEL 4497/1947 és 1176/1948.

31 PEL 3174/1948. Püspök Pál levele 228/1948.

32 Datált ajtó és korlátterv: BTM KM ÉGy VII/2. 68.138.26_15,18.(1949.II.); kisajtók tervei:VII/2.68.138.26_13, 17. (1949. III.); főkapu terve: VII/2. 68.138.26_14. (1949. IV. 9.)

33 U. A.: Szól a gerjeni harang. Új Ember 10. 1950: 35, 3. Pusztai 1972, 61; Szekeres-Virág 1982, 146, 149; Tölgyes 1999, 78; Winkler-Domján 2010, 142 1946-ot ír. UrbánVukoszávlyev 2016, 13 1948-1949-re, Vukoszávlyev-Urbán 2016, 288 1948-ra, Árkay Müjegyzéke pedig 1949-re datálja Gerjen templomát.

34 Árkay műjegyzékében nem szerepel, UrbánVukoszávlyev 2016, 35, 36 tévesen Árkay hatvanas évekbeli felújításai közé sorolja.

35 A BTM KM EGY 68.138.47. számú terv a leltárkönyvében „Kömöczi templom”-ként, felirat és jelzet nélkül szerepel, versóján viszont Kömpöcz felirat olvasható. A másik tervet „Kerepesi templom padok”-ként azonosították, miközben a jobb felső sarokban a „Kömpöczi R.k. templom padrajza" felirat szerepel. (BTM KM ÉGy 68.141.1_3. é. n.) Ezen terv alapján készültek a plébánia másik filiájának, Kígyóspuszta templomának padjai is. VPKL AP Kiskunmajsa 241/58.

36 VPKL AP Kiskunmajsa 489/49. Rétei Gyula plébános levele 101/1949.

37 VPKL AP Kiskunmajsa 2030/53. A használatbavételi engedélyt azzal a kikötéssel kapták meg, hogy 1954 őszére befejezik a külső vakolást is. Uo. 2606/53. Rétei levele 167/1953. A tervtől a torony nyolcméteres magasításával, valamint a szentélyablakok áthelyezésével eltértek. Uo. 2730/57. Palotás József káplán levele (isz. n.)

38 VPKL AP Kiskunmajsa 2730/57. Palotás József káplán levele (isz. n.)

39 VPKL AP Kiskunmajsa 1245/60. Pongrátz Gergely plébános levele (18/1960)
40 HD Kiskunmajsa 118-121.

41 Cséfalvay 1988, 462; Urbán-Vukoszávlyev 2016, 22. Ugyanők másutt azt írják, hogy „,anekdotikusan köztudott [, hogy] Árkay Győr-Kisbácsai (...) temploma ugyancsak ideatervként született." Vukoszávlyev-Urbán 2016, 307.

42 Hartmann 2016, 48.

43 BTM KM ÉGy 68.138.24_1, 8. (1957), 68.138.24_2, 7, 9 (é. n.). A felirat és szignó nélküli, kerítéstervként azonosított ceruzarajz (68.138.24_7) semmiképpen sem kerítéshez készült, ugyanis magán a rajzon olvasható a „kórus beton” felirat, a kisbácsai templom kóruskorlátja viszont ilyen kialakítású. Ahogyan Horté és Taksonyé is (1.: Lantos 2016b, 325), de a soproni templomhoz készült terveken is ilyen korlátkiképzés látható. BTM KM ÉGy 68.138.45_73-74. (é. n.) és 68.138.45_94 (Felirata: „Oldalerkély vb. mellfala")

44 BTM KM ÉGy 68.138.24_1. (1957. VI. 1.), 2. és 9.

45 BTM KM ÉGy 68.138.24_8. (1957. VIII. 18.)

46 Biczó 2007, 183.

47 Biczó 2007, 184. Pusztai 1972, 61; Szekeres-Virág 1982, 147, 149; Tölgyes 1999, 78 1960-ra datálja, Winkler-Domján 2010, 142 pedig 1957-re. Barla-Szabó 1992, 100 1960-at ír. Árkay Mújegyzékében 1955 áll.

48 Takács 2008, 11. és 61.

49 A tervhez képest a teljes épület kőborítású lett, és nincs meg a mennyezet lépcsőzetessége. A jelenlegi faborítású síkmennyezet, és a szentély kazettás kialakítása az 1978-as felújítás eredménye, amikor kicserélték a tetőt, megszüntetve ezzel a beázásokat. Takács 2008, 22-23 és Biczó 2007, 185.

50 BTM KM ÉGy 68.138.37_1-2. és 24 (é. n.). Előbbi kettő pauszra tussal, utóbbi papír, színes ceruza és tollrajz.

51 BTM KM ÉGy 68.138.37_2-23 (é. n.).

52 A megvalósult homlokzat jelenik meg a 68.138.37_15. terven. Valószínűleg nem ide tartozik egy oltárterv (BTM KM ÉGy 68.138.37_3), amin a tabernákulum fölött a keresztre feszítés látható a tizenkét apostollal, egy keresztmetszeti rajz (68.138.37_18), ahol a diadalív két oldalán szószék, illetve fülke nyílik, amit a feliratozott tervek nem jelölnek, illetve az oltárképen Mária-ábrázolás vehető ki, miközben a templom titulusa Szent Márton. Ugyancsak kétséges az ideköthetősége a vakárkádos homlokzatú, jobb oldali külön álló tornyos templom rajzának (68.138.37_7). A hajó tetőgerince fölé magasodó szentélylefedés (68.138.37_8, 10-13, 16), illetve altemplomos verziók $\left(68.138 .37 \_5-6,9\right)$ tervezését a levéltári források nem támasztják alá. A szalkszentmártoni építkezéshez kötésük a feliratozott tervek részleteivel (pl. a főhomlokzat kereszt vagy körablak motívumával, a mellékhajó árkádjaival) való megegyezés lehetett. A főhomlokzat első tervének (illetve Kisbácsa templomhomlokzatának) további verziói: 68.138.37_4, 14, 17, 19-23.

53 VPKL AP Szalkszentmárton 3921/1957. dr. Kovács Vince levele 3936/1957.

$54 \mathrm{Az}$ elsőnek tervezett épület nem fért rá a telekre. Az épület elforgatásától a rövidítéséig több lehetőség felmerült, végül a telek kiterjesztése és az épület áttervezése együtt jelentette a megoldást. VPKL AP Szalkszentmárton 461/1958. és 1050/1958. iratcsomók.

55 Regőczi 1988, 368.

56 Regő́czi 1988, 370.

57 Regöczi 1988, 371. 
58 Regőczi 1988, 372.

59 VPKL AP Szalkszentmárton 461/1958. Regőczi levele isz. n. Árkay Müjegyzékében 1964. Urbán-Vukoszávlyev 2016, 27: „'50-es évek vége"; Vukoszávlyev-Urbán 2016, 307 1957-re teszi.

60 BTM KM ÉGy 68.138.33_16-18. (é. n.) Mindhárom nyeregtetős, - a templom arányaihoz képest - nagyon magas oromzatot mutat. Kettőn az egyenes záródású kapu fölött kereszt, afölött három, illetve négy háromszög alakú csoportban széles és alacsony félköríves nyílások kaptak helyet. A harmadikon hat-hat félköríves nyílás sorakozik egymás fölött három oszlopban. Ezek a megoldások nem köthetőek sem a vecsésiként azonosított tervekhez, sem a megvalósult épületekhez, és a hagyatékban több hasonló homlokzatvariáció is van. Pl. Uo. 68.141.5_19-21 és 25-28 (mind helymegjelölés és évszám nélkül).

61 BTM KM ÉGy 68.138.33_3-5, 68.138.33_13 és 68.138.33_15.

62 VPKL AP Vecsés Andrássy-telep 4835/1948. Kovács A. levele 208/1948.

63 VPKL AP Vecsés Andrássy-telep 5490/1948. Dr. Galamb Tibor 4568/1948. sz. határozata, Helle László levele 6833/1948.

64 VPKL AP Vecsés Andrássy-telep 5490/1948. Kovács A. levelei 240/1948. és 260/1948.

65 VPKL AP Vecsés Andrássy-telep 6517/a/1948. Kovács A. levele 297/1948.

66 Ezt a templomot az 1853-ban épült neogótikus Weber-Saxlehner-palotából alakították ki 1929-1930-ban Szörényi-Reischl Gusztáv okleveles müépítész tervei alapján. Az épület 1929-ben került a rend tulajdonába. 1945-ben még állt a négy fala, bontási terve 1949. január 7-re datált. Bíró 2010, 236-239, 242.

67 VPKL AP Vecsés Andrássy-telep 6865/1948. Kovács levele 300/1948.

68 VPKL AP Vecsés Andrássy-telep 3015/1950. Kovács A. levele 101/1950. Az akadályok közt volt, hogy az iskola nem engedélyezte tovább annak a két tanteremnek a használatát, ahol addig miséztek. Emiatt inkább kibővítette az egyházközség kultúrházában kialakított szükségkápolnát, amit a templomépítés idején használtak. Szintén Kovács A. irányította 1949-1950-ben a Halmi-telepi Szent Erzsébet kápolna felépítését. (Uo. 3593/1949, 2340/1950. és 2280/1950. iratcsomók) Gondot okozott, hogy betegeskedni is kezdett, és sok pénz elment a gyógykezelésére. VPKL AP Vecsés Andrássy-telep 4937/1949. Kovács levele 194/1949.

69 VPKL AP Vecsés Andrássy-telep Iktatókönyv 1955-1961. 1956. 05. 20. a Községi Tanács VB levele 58171/1956.

70 Részletesebben 1.: Lantos 2016a, 98-99.

71 VPKL AP Vecsés Andrássy-telep 1920/1957. Bognár levele 72/1957.

72 MNL PML XXIII.23-a 1957. 60.139/1957. Csala levele 2543-2/39-4/1957.

73 VPKL AP Vecsés Andrássy-telep 836/1958. Bognár levele 11/1958.

74 VPKL AP Vecsés Andrássy-telep 2818/1958. Bognár levele 120/1958.

75 VPKL AP Vecsés Andrássy-telep 2818/1958. Bognár levele 120/1958. és VPKL AP Vecsés Andrássy-telep Iktatókönyv 1955-1961. 167/1958.
76 VPKL AP Andrássy-telep 4678/1958. Bognár levele 252/1958. és s. n.: Megáldották Vecsés-Andássy-telep új templomát. Új Ember 14. 1958: 52. 2.

77 VPKL AP Andrássy-telep 1508/1959. Bognár levele 191/1959., 1730/1959. Bognár levele 68/1959. és 2146/1960. Bognár levele 130/1960.

78 VPKL AP Andrássy-telep 2511/1962. Bognár levele 193/1962.

79 VPKL AP Andrássy-telep 2511/1962. Bognár levele $5 / 1963$.

80 VPKL AP Andrássy-telep 1063/1964. Bognár levele 64/1964., 2503/1965. Bognár jelenti 262/1965. és 2574/1965. Bognár levele 219/1965.

81 Árkay az eredeti tervén a hajóba lépcsőzetesen kialakított kazettás mennyezetet tervezett. Az elkészült épületben a kazettás kialakítás megvan, és a két szélső, szélesebb síkmennyezet-szakasz is, de középen csúcsívet alkotnak a négyzetes kazettasorok.

82 Doromby Károly: Megvalósul a Vecsés Andrássy-telepi hívek régi álma. Új Ember 13. 1957: 28, 2.

83 Cséfalvay 1988, 462; Urbán-Vukoszávlyev, bár tisztában van vele, hogy csak „az épülettömeg logikus lezárása és a toronyformálás kialakítása várt" Árkayra, mégis Kreybiggel „közös tervezés”-ként említik, illetve elemzéseikben ezt az épületet is Árkay müveként kezelik: Urbán-Vukoszávlyev 2016, 13, 28.

84 VPKL AP Hernád 381/1957. Bányai Aladár lelkész levele 1/1957. és MNL PML XXIII.23-a 1957. Csala László levele 91.124-1/1957.

85 VPKL AP Hernád 2487/1958. 1699/1960. Bányai jelentése.

86 U. A.: Kápolna megáldás Hernádon. Új Ember 16. 1960: 38, 2. Árkay Müjegyzékében 1956. UrbánVukoszávlyev 2016, 13 és Vukoszávlyev-Urbán 2016, 307 1961-re datálja.

87 VPKL AP Hernád 2429/1963. Bányai levele 12/1963. és 1486/1964.

88 VPKL AP Kakucs 1514/1956. Az egyházközség levele (isz. n.), 1514/1956. Vincze levele 75/1956.

89 MNL PML XXIII. 23-b. Csala László levele E.III-6/1957.

90 VPKL AP Kakucs 3592/1957. és 4807/1957. iratcsomók 91 VPKL AP Kakucs 2268/1958. Vincze levele 62/1959. és 132/1959., 2906/1959. Vincze levele 415/1959.

92 VPKLAP Kakucs 1700/1959. Vincze levele 1017/1960. és 229/1961. Vincze levele (isz. n.) Végül úgy döntöttek, hogy sisakkal lezárják a tornyot ott, ahol tartanak (ez a keresztmotívum fölött volt kb. egy ablaknyi magassággal), és amikor lehetőségük lesz, folytatják. VPKL AP Kakucs 1409/1961. Vincze levele 709/1961. és VPKL VII. Gyüjtemények 3. B. V. Inárcs.

93 VPKL AP Kakucs 1626/1962. Vincze levele (isz. n.) és s. n.: Templom épült a krumpliföldeken. Új Ember 18. 1962: 38. 3. Arkay müjegyzékében 1956.

94 BTM KM ÉGy 68.138.43_1-6. Szignált: 1, 2. (mindegyik é. n.)

95 BTM KM ÉGy 68.138.43_5.

96 BTM KM ÉGy 68.138.43_3-4.

97 Az 1945 utáni időszakban a felhasznált építőanyagokat a könnyen, olcsón beszerezhetőség határozta meg, így kevés esélye van annak, hogy Árkay ezeket a terméskő homlokzatokat erre a helyszínre tervezte volna. 
98 BTM KM ÉGy 68.138.43_6. Urbán-Vukoszávlyev 2016, 33 ezt a tervet úgy interpretálja, hogy „Árkay e rajzával bizonyítja, hogy a szükös anyagi lehetőségek ismeretében sem mondott le idea-képeinek megfogalmazásáról, legalább papíron". Hogy ez valóban így volt, azt Árkaynak számos megvalósulatlan tervvázlata (többek közt: 68.141.5_1-65) bizonyítja. Ám (ha el is tekintünk a háttér hegyeitől), arra, hogy ezt a rajzot épp a móricgáti szük költségvetés fölötti ábrándja ihlette volna, nincs bizonyíték.

99 VPKL AP Móricgát 1957. 4048/57. Varga 1997, 267.

100 MOL-XIX-A-21-b Móricgát 1958. a Szanki községi Tanács VB (10-83/1958) határozata.

$101 \mathrm{Ez}$ a terv egy toronnyal épült változat lehetett, mert Szakács Gyula egyházügyi előadó június 13-i levelében azzal a kikötéssel javasolja az ÁEH-nak az engedély megadását, ha átdolgozzák a tervrajzot „és a toronynélküli imaházat kell engedélyezni". (MNL OL XIX-A-21 Móricgát 1958. Szakács levele 31208/2/1958.) Kónya júniusban is sürgeti Árkayt, hogy „sürgősen készítsen tervet és azt június 15-ig küldje Vácra". VPKL AP Móricgát 2488/1958. Kónya levele 95/1958.

102 Erről és a segélyért folyamodás módjairól részletesebben 1.: Lantos 2016a 63-65.

103 VPKL AP Móricgát 3358/1958. Kónya levele $118 / 1958$

$104 \mathrm{Ha}$ ez volt a májusi engedélyezési terv szerinti templom látványrajza, akkor különösebb áttervezés nem történt, Árkay csupán elhagyta a tornyot és árkádot.

105 s. n.: Móricgáton... Üj Ember 15. 1959: 46, 4. Árkay Müjegyzékében 1959. Vukoszávlyev-Urbán 2016, 306. és 307. szerint 1964.

106 68.138.29. (é. n.) Árkay Müjegyzékében ez a település nem szerepel.

107 s. n.: Épülő templomok rovat: Tiszalök. Új Ember 4. 1948: 17, 8. EFL AN AP Tiszalök 1264/1947, 1751/1947.

108 EFL AN AP Tiszalök 4336/1959.

109 EFL AN AP Tiszalök 1392/1960.

110 BTM KM ÉGy 68.138.41. (é. n.)

111 EFL AN AP Tiszagyulaháza 7684/1943.

112 EFL AN AP Tiszagyulaháza 3808/1944. A fenti idézet is jól mutatja a Magyarországon a barokk korig viszszavezethető templomtípus-tervezési gyakorlat (Kelényi 2013, 487) 20. századbeli továbbélését. Ez a folytonosság újabb érvet jelent a típustervezés építészettörténeti helyének továbbgondolásához. Lantos 2014, 391.

113 EFL AN AP Tiszagyulaháza 818/1958. Bodnár levele $7 / 1958$.

114 EFL AN AP Tiszagyulaháza 2452/1958. és 2862/1958. iratcsomók. Árkay müjegyzékében 1963-asként szerepel.

115 EKM Cséfalvay-hagyaték, Adatgyüjtés, Újtikos, EFL AN AP Tiszagyulaháza 3601/1959. Arkay Müjegyzékében 1963. Vukoszávlyev-Urbán 2016, 307 szerint 1964 k.

116 Mind tipikusan olyan eltérés, amit részben az anyagiak (nyílászárók száma), részben a helyi mesterek technikai felkészültsége (körablak és nagyobb fesztávú félköríves áthidalás építése) befolyásol.

$117 \mathrm{Az}$ iratok szerint $8 \times 16 \mathrm{~m}$ nagy épület felhúzásához kértek engedélyt. Eszes István költségvetése 120 $\mathrm{m}^{2}$ alapterületű épületről beszél (EFL AN AP Tiszagyulaháza 818/1858), Árkay tervén pedig a templom hajója $7 \times 16 \mathrm{~m}\left(112 \mathrm{~m}^{2}\right)$, szentélye 5,24×3,02 m.

118 A plébániai honlap az iskolakápolna átépítésének tekinti az épületet (URL: http://www.polgariplebania.hu/ templomunk.php Utolsó megtekintés: 2017. április 22.), pedig a levelezésből kiderül, hogy a községi Tanács VB épp amiatt támogatta a templomépítést, mert az egyház kiköltözésével az oltárfülke/sekrestyeszoba irodává vagy szertárrá alakítható át. EFL AN AP Újtikos 818/1958.

119 BTM KM ÉGy 68.138.33_7-12. és 68.138.33_14 (mindegyik é. n.).

120 BTM KM ÉGy 68.138.33_1-2, 68.138.33_6 (mindhárom 1960).

121 BTM KM ÉGy 68.138.33_11 és 12.

$122 \mathrm{Az}$ oldalnézetek főhomlokzatra utaló jelei oromzatot nem, csak egy konzolra támaszkodó keresztet jelölnek, ami szintén nem egyezik a föhomlokzat rajzával.

123 A helyiségre az altemplom és a pince kifejezést is használták. VPKL AP 149/1961. Kovács I. levele 64/1961. és VPKL Az OKGyK Nyilvántartási kérdőívei 1970. Vecsés Óplébánia 3.

124 Szabó 1958, 390.

125 VPKL HD Vecsés Óplébánia s. p. [1944]

126 MNL PML XXIII.23-a. 70.618/1959. Vetróczky? Imre levele 30/1959.

127 VPKL VII. Gyüjtemények 3. B. V. Vecsés Ófalu, a képeslap hátulján a plébános kézírásával: Domokos Ottó okl. ép. mérnök Budapest

128 VPKL AP Vecsés Óplébánia 913/1954. VPKL HD Vecsés Óplébánia s.p. [1948. IX. 18.] és [1953 őszén]

129 A bontás indokaként merült fel, hogy a félbemaradt építés miatt a falak életveszélyessé váltak. (VPKL HD Vecsés Óplébánia s. p. [1959. okt. 10-től]) Másutt, hogy illetéktelenül építkeztek. A járási szervek szerint ugyanis tisztázatlan volt a telekkönyvezés és az építési engedély kiadása. Kovács István 1960-ban kiderítette, hogy 1947-ben a Járási Főjegyzőtől egy telekcsere eredményeként megkapták a telket, de azt telekkönyvileg nem írták az egyházközség nevére. Ahogyan 1948-ban az építési engedélyt is megkapták ugyanonnan. (VPKL AP Vecsés Óplébánia 459/1960. Kovács I. levele 262/1960.) De az is elhangzott, hogy amiatt nem engedélyezik „mivel az foútvonalon van és a bejárat nagymértékben veszélyeztetné a foútvonalon való gépjármü közlekedést". (MNL PML XXIII.23-a 28/1960.)

130 VPKL AP Vecsés Óplébánia 459/1960. iratcsomó.

131 VPKL AP Vecsés Óplébánia 149/1961. Kovács I. levele 163/1961, 1985/1961. Kovács I. levele 219/1961, 3613/1961. Kovács I. levele 311/1961. és 798/1962. Kovács I. levelei 113 és 128/1962.

132 s. n.: Új templom megáldása Vecsésen. Új Ember 18. 1962: 24. 1. Árkay Müjegyzékében egyszer szerepel Vecsés, 1959-es évszámmal.

133 VPKL AP Vecsés Óplébánia 3385/1962. Kovács I. levele 349/1962. és 2376/1963. Kovács I. levele 173/1963.

134 Nem ismerve az eredeti terv méretezését, elképzelhető, hogy nem Árkay futtatta végig a mellékhajót az eredeti tervhez képest, hanem a rövidített épület elképzeléshez alkalmazkodott.

135 BTM KM ÉGy 68.138.35. (é. n.) A leltárkönyv csak templomként azonosítja, és a terv feliratát („Pátroha r. k. plébánia templom terve") nem közli.

136 Noha az épület torony nélkül épült, VukoszávlyevUrbán 2016, 307 azok közé a templomok közé sorolja, ahol Árkay „felismerve az építtetői igény »konzervativizmusát «, nem tért el a hagyományos középtornyos formától."

137 MNL OL XIX-A-21-b. Pátroha 1961. Som Ferenc plébános levele 36/1961 és Buhalla levele 150/1961. 
138 Magyar Ferenc: Ezüstvasárnap egy szabolcsi faluban. Új Ember 17. 1961: 12, 2. Árkay Mưjegyzékében 1963. Vukoszávlyev-Urbán 2016, 307 szerint 1960 k.

139 BTM KM ÉGy 68.138.39. (1962)

$140 \mathrm{Az}$ Urbán-Vukoszávlyev 2016, 35 állítása szerint „nagy viszontagságok közepette létrejött templomocska” elkészüléséhez valójában - az 1962 januárjában megfogalmazódott építési szándék, és a novemberi felszentelés közti - 10 hónap (engedélyezéssel és építkezéssel együtt) gyorsnak tekinthető.

141 EFL AN AP Parád 91/1962. Szörényi levele $10 / 1962$.

142 EFL AN AP Parád 1617/1962. Képviselőtestületi jegyzőkönyv.

143 EKM Cséfalvay-hagyaték, Adatgyűjtés, Parádsasvár Árkay Müjegyzékében nem szerepel.

144 BTM KM ÉGy 68.138.36_1 és 3-11. (é.n.), 2. 1964. Biztosan ide készült a kovácsoltvas elemekkel ellátott kapu (és annak változata) terve, egy homlokzatvázlat, egy rácsos tartó és egy toronysisak szerkezet-tervei (Uo. 2. és 8, 3, 11 és 4.) A 68.138.36_5-6-os homlokzatterven és a méretezett, kórus felöli keresztmetszeten a torony, a homlokzat, a kapu, de a kórus kialakítása sem a megvalósult eszlárit, hanem a hernádi templom homlokzatát és (a korlát falazását leszámítva) kórusmegoldását követi. A templom titulusa (ami nem Szentlélek, mint a berendezésen ábrázolt, hanem Nagyboldogasszony) alapján kétséges a berendezésként, illetve valószínúleg a szőlő és kalászdíszként azonosított vázlatok helye is. Uo. 7. és 9-10.

145 Sinkó Ferenc: Tüz és víz felett. Új Ember 9. 1949: $42,2$.

146 EFL AN AP Tiszaeszlár 2092/1945, 2186/1961, 2560/1962, 209/1963. iratcsomók.

147 A küklopsz falazat kialakítása a vállalkozótól származik. Szabó három verziót ajánlott: (1) küklopsz a falazaton és a lábazaton, kváder a sarkokon és a nyílászárók körül, (2) kváder falazat, küklopsz lábazat - mindkét verzióban kőpárkánnyal elválasztva a lábazatot, és (3) egységes kváder falazatot, lábazat elkülönítése nélkül. Ezt Árkay kezdetben ellenezte, majd a három változatból a harmadikat pártolta. Végül az érsek szava döntött, és a párkánnyal elválasztott küklopsz falazat-lábazat verzió valósult meg. EFL AP AN Tiszaeszlár 1025/1964. Csékán levele (isz. n.) és Brezanóczy 04. 16-i levele.

148 EFL AN AP Tiszaeszlár 103/1964. Csékán levele (isz. n.).

149 EFL AN AP Tiszaeszlár 527/1964. Csékán levele (isz. n.) A hatósági engedély 1965. 05. 25-én érkezett meg. EFL AN AP Tiszaeszlár 1562/1964. dr. Szabó Gyula VB titkár levele.

150 EFL AN AP Tiszaeszlár 830/1964. Ugyanakkor érthetetlen (de talán a toronyépítés tilalmának már akkor masszívan élő tévhitét alátámaszthatja) Árkaynak (aki a horti templom toronypárját tervezte) az a Brezanóczyhoz (aki ugyanezt 1960. július 10-én felszentelte) írt mondata, miszerint: „Örülök, hogy elvben már megengedték a torony építését. Ez talán az első a háború után!" EFL AN AP Tiszaeszlár 790/1964. Az 1945 utáni időszak toronyépítési tilalmáról 1.: Lantos 2016b, 338, 42. j.

151 EFL AN AP Tiszaeszlár 2636/1965. Árkay Műjegyzékében 1963.

152 A tervező és kivitelező/megrendelő eltérő véleménye a falazatról csak az egyik eleme volt az egyház- község és Árkay nézeteltéréseinek. A másik Árkay késlekedése volt a tervekkel és a költségvetéssel. (EFL AN AP Tiszaeszlár 790/1964, 1158/1964. Csékán levele 18/1964.) Ám ami a legsúlyosabb lehetett, hogy a csak három éve felszentelt templom beázott: „A tetöre nem lett tervezve kibúvó. A padlástérbe bemenni nem lehet. A pala alá bekerült hó olvadása mindig elnedvesedést okoz, ami - tekintettel arra, hogy a mennyezet egyszerü nádpalló később komolyabb problémákat okozhat." A mennyezet szigeteletlensége és az egyrétegű vasszerkezetes ablakok miatt „,a templom kibírhatatlanul hideg, úgy hogy télen a hideg miatt a hívek templombajárása (sic!) a minimumra csökken". EFL AN AP Tiszaeszlár 536/1968. Csékán levele 48/1968.

153 Jászdózsán 1954-ben tervezték újra felépíteni az 1944-ben felrobbantott, a község határában álló 16. századi kápolnát, de annak megépítését az eredeti tervek követéséhez kötötték (EFL AP AN Jászdózsa 1950(1313/1954). 1970-ig ezen kívül csupán a toronysisak javításáról és újrafestéséről, a templom és a plébánia külső tatarozásáról és a versus populum oltár felállításáról van adat. (Uo. 3544/1954, 333/1962, 1086/1963, 1327/1964, 2377/1968.) Felsőgödön pedig a Bócsa-pusztai kápolnaépítéshez készülhetett terv, ám a plébániai levelezés nem említi Árkayt. (Varga 1997, 144.) Árkay Müjegyzékében Jászdózsa 1963, Felsőgöd 1950.

154 Pestszentimrét Árkay Müjegyzéke 1963-ra datálja. Mind a hagyatékban fennmaradt terv (BTM KM ÉGy 68.95.3-6, 1959. I. 6-10.) felirata, mind az inárcsi templom építése kapcsán született Árkay-levél, amiben azt írta, hogy „, a felrobbantott templom befedésének tervezése folyamatban van" (VPKL AP Inárcs 56/1958. Árkay 1958. 01. 03-i levele) egyértelmüvé teszi, hogy itt csupán tetőhelyreállítás történt. Szintén helyreállítás volt a polgári torony (a mújegyzékben 1956-ra datálva), melyet annak tervei (párkányprofilok és a homlokzatrajzok BTM KM ÉGy 68.138.27_1-3. é. n.), és a levéltári kutatás is megerősít: 1957 júniusában a „tervrajzok megérkeztek Árkay Bertalan építészmérnöktől. A műemlék jellegű templom helyreállításának terveit a tervező művész az eredeti állapotnak megfelelően készítette el." (EFL AN AP Polgár 2780/1957. Képviselőtestületi jegyzőkönyv.) Megáldása 1959. augusztus 16-án volt (EFL AN AP Polgár 2927/1959. Dr. Tajti Lajos levele isz. n.). Pusztai 1972, 61; Szekeres-Virág 1982, 149; Tölgyes 1999, 78 és Winkler-Domján 2010, 142 is 1954-re datálja. Ráadásul nem az egész templom rekonstrukciójáról volt szó (ahogy Pusztai és Szekeres-Virág is állítja), hanem a torony és a kórus, illetve a tetőzet két hajónyi szakaszának újjáépítéséről. Urbán-Vukoszávlyev 2016, 13 ugyanezt az adatot ismétli, majd másutt azt állítja, hogy 1954-esek a tervek, és a felújítás 1958-ban fejeződött be (Uo. 15.). Mindkét adat téves, ahogyan az 1954-et ismétlő másik közlés is (Vukoszávlyev-Urbán 2016, 268).

155 Árkay a műjegyzékében 1964-re datálja a kerecsendi új templomot, amit pedig 1950-ben kezdtek el építeni a mai helyén (EFL AN AP Kerecsend 466/1946. és 1120/1960. iratcsomók). 1952-re álltak a falai (Uo. 876/1954). Árkay 1959-ben a templom tetőszerkezetének terveit készíti (Uo. 3038/1959. Képviselőtestületi jegyzőkönyv)

156 EFL AP AN 1535/1965. A tabernákulumajtó, a gyertyatartók és a feszület Tattay György munkái. Árkay Müjegyzékében 1963. 
$157 \mathrm{Az}$ alagi templomhoz (a Müjegyzékben 1950) van a hagyatékban terv, 1933-ra datálva (BTM KM ÉGy 68.138.9, 68.138.38_1-12. és ltsz. n. 2-4). Alagon a háborús károkat 1957-ben renoválták (Varga 1997, 19).

158 VPKL AP Alag 1933-1972. 914/1933. A Képviselőtestületi ülés jegyzőkönyve.

159 VPKL AP Alag 1933-1972. 5936/1936.

160 BTM KM ÉGy 68.138.40_4.

161 BTM KM ÉGy 68.138.40_1-3, 5. (é. n.) A nyárási templomterv annyiban tér el a tiszalökitől, hogy ott a szentély jobb oldalához L alakban plébánia is csatlakozik, a hajó falán párosával nyílnak a keskeny, félköríves ablakok, és a homlokzaton a kapu félköríves, illetve fölötte nem angyal, hanem keresztmotívum található

162 VPKL AP Nyáregyháza 1910-1957. 1159/57.

163 PML XXIII. 23-B 77.208/1/1959; VPKL AP Nagykőrös III. 2158/1959.

164 BTM KM ÉGy 68.138.44, Balog 2005, 118-119.

165 BTM KM ÉGy 68.138.23_5, 68.138.45_27, 30, 44.

166 Pusztai 1972, 61; Szekeres-Virág 1982, 147, 149; Tölgyes 1999, 78 és Winkler-Domján 2010, 142 is 1946-ra datálja. Urbán-Vukoszávlyev 2016, 13 egyszer „1948-ban felépült”, másszor „1948-49. évi építéstörténet”-ről ír (Uo. 16-17). Mindkét állítás pontatlan, ahogyan a kultúrháznak indult épületáttervezés is (Vukoszávlyev-Urbán 2016, 290). A horti templom építéstörténetét részletesen 1 .: Lantos 2016b, 320-322.

167 Pusztai 1972, 61; Szekeres-Virág 1982, 147 és 149 és Töloyes 1999, 78 szerint 1956-os. Winkler-Domján 2010, 142 is 1956-ra teszi, de helyreállításnak nevezi. Barla-Szabó 1992, 100 szerint 1957-es.

168 A tervek alapján a ceglédi templom is a horti és taksonyi templomok sorába illeszkedett volna.

169 Terv: Lőrinc, Móricgát, Nyárás, Szalkszentmárton (68.138.37_2), Parádsasvár, Pátroha, Tiszalök. Megvalósult Szalkszentmárton.

170 Sokszögű záródású Kömpöc, Újtikos és Tiszaeszlár szentélye, téves tehát Urbán-Vukoszávlyev 2016, 33 állítása, miszerint Árkaytól szokatlan lett volna a poligonális szentélyzáródás. A hajóval egyterü, csapott sarkú szentélyes Hernád, egyenes záródású Pátroha és Parádsasvár, félköríves Gerjen és Inárcs, és két keskeny egyenes szakasz közt szegmensíves megoldású Móricgát és Vecsés Óplébánia temploma.

171 Hernád, Móricgát (BTM KM ÉGy 68.138.43_2), Nyárás (Uo. 68.138.40_1, 3.), Pátroha (Uo. 68.138.35), Szalkszentmárton kéthajós terve (Uo. 68.138.37_1), Tiszalök (Uo. 68.138.29) és Vecsés - Óplébánia (Uo. 68.138.33_1, 6) Figyelemre méltó Árkay templomainak ezekhez a historizáló részletekhez való ragaszkodása.

172 Utólagos hozzáépítés Szalkszentmárton tornya (1996-ban, forrás: emléktábla a templomon) és Kisbácsa templomának íves árkádsora és a tornya is, amelyek Petrovicz Attila építész tervei szerint épültek 2008-ban. Petrovicz Attila: Római katolikus templom - Kisbácsa URL: http://epiteszforum.hu/gyor-kisbacsa (Utolsó megtekintés: 2017. 04. 21.)

173 A főhomlokzat tető fölé magasodó és nyílásokkal ellátott pengefala, ami a mediterráneum templomépítészetében gyakran harangokat hordoz, itt csak némi csúsztatással alkalmazható, mivel Árkaynak ezek a speciális oromzatai egyik esetben sem hordoznak harangot.

174 Idézetek: Urbán-Vukoszávlyev 2016, 25. és 28.
175 Urbán-Vukoszávlyev 2016, 27 Tiszalök és Nyárás terveiről is úgy gondolják, hogy „bizonyos, hogy mindkét tervet az '50-es évekre lehet datálnunk. A hagyatékban a tiszalöki templom terve a polgári helyreállítási terveket követi, míg a nyárási az évtized végén megvalósuló tervsorozatok között van (repertórium szerinti datálása 1958). Polgár templomának felújításában Árkay az '50-es években vesz részt - az egyházi kapcsolatok, de leginkább a személyes ismeretségek okán feltételezhetjük e tervek elkészültének időszakát is ezzel azonosítani". A leltárkönyv alapján történő kronológiai elhelyezés legalább annyira problémás elképzelés, mint ugyanitt az egyházi kapcsolatokra való (adatokkal nem alátámasztott) hivatkozás. (A leltárkönyv excel-file-jában Tiszalök terveit megelőző datált jelzetü terv az 1949-es ceglédi, utána pedig az első évszám jelzettel ellátott a parádsasvári imaház terve [1962]. Leltári szám szerint a tiszalöki [68.138.29] előtt a váci székesegyház tervei jönnek, amit a péceli templomtervek követnek.)

176 Urbán-Vukoszávlyev 2016, 30.

177 Urbán-Vukoszávlyev 2016, 30.

178 Láng 2008, 12 és VPKL AP Kakucs 56/1958. Árkay levele.

179 Urbán-Vukoszávlyev 2016, 33. Ugyancsak kronológiai tévedés, amikor úgy vélik, hogy a tiszaeszlári anyagválasztás - ami, mint láttuk, nem is Árkaytól származott - „visszahatással lehetett a móricgáti vázlatban megfogalmazott anyagválasztásra". (Tiszaeszlár tervezése: 1963-64, felszentelése: 1965, Móricgát tervezése: 1958, felszentelése: 1959.) Uo. 35.

180 Urbán-Vukoszávlyev 2016, 38.

181 Szalkszentmárton, Vecsés és Móricgát templomaiban a szentély lépcsővel megemelt, (Vecsés kivételével pedig még) diadalívvel is elválasztott térszakasz, tehát egyik sem teremtemplom.

182 Urbán-Vukoszávlyev 2016, 38.

183 Hernád esetében ilyenről gyakorlatilag nem beszélhetünk. Az ÁEH részéről Csala László az első kérelem után megadta a templom és a plébánia építési engedélyét. (MNL PML XXIII.23-a 66.122/1957.) Sőt, miután 1959-ben kiderült az a szabálytalanság, hogy az engedélyt egy plébániával egybeépített templomra kapták, ezzel szemben különállókként építették fel azokat, sem történt olyan, ami megakadályozta volna a templomépítés befejezését. MNL PML XXIII.23-a 1959. 70.660/1959. Kancsár István Dabasi Járási Tanács VB elnök levele (0025/1959) a Pest megyei Tanács VB elnökének.

184 Vukoszávlyev-Urbán 2016, 307. A szakasz szó szerint megegyezik előző tanulmányuk vonatkozó passzusával (Urbán-Vukoszávlyev 2016, 13.).

185 Ugyanők azt is állítják, hogy „a középtornyos falusi templomminta egyenletes megújulása az 1960-as években éri el fordulópontját." Vukoszávlyev-Urbán 2016, 311.

186 Vukoszávlyev-Urbán 2016, 307.

187 EFL AN AP Cserépváralja 2946/1959. iratcsomó. A tervvázlatokról 1. 1. j. Lantos 2017.

188 Már Cséfalvay Pál is úgy véli, hogy Árkay „variálja itáliai hatásokra utaló, kis, nyitott harangtornyos, belül nagyon egyszerü típusterveit (...) Vecsésen kettőt, Móricgáton, Szalkszentmártonban, továbbá komolyabb szinten Kisbácsán." Cséfalvay 1988, 462. De ez sem áll meg, hiszen mindössze a Vecsés Andrássy-telepi templomnak van tornya, a többi épület kialakításai pedig eltérnek egymástól. 
189 Major 1983, 309. Major Máté definícióját - történeti kontextusba helyezve - úgy vélem pontosabbnak, ha a tudományos helyett a tudatos szót használjuk.

190 Urbán-Vukoszávlyev 2016, 13 és 25-27. Természetesen mindhárom homlokzat eltér arányaiban is. Szalkszentmárton $11 \mathrm{~m}$ magas főhomlokzatán a kapu szemöldöke 2,9, az előtető 3,1 m magasan van. Tiszalökön az előtető 3, a két lépcsővel megemelt kapu szemöldöke 2,8 m magasan van, Nyáráson nincs előtető, és a kapu záróvonala $3 \mathrm{~m}$-re tehető. Mivel az előbbi épület teljes, az oromzat vonaláig mért magassága $10 \mathrm{~m}$, míg az utóbbié 10,5, a kapu fölötti kereszt-, illetve angyalmotívum mezője is eltér méretében.

191 BTM KM ÉGy 68.138.29, 68.138.40_1. és 68.138.37_24: Tiszalök és Nyárás tervén az oromzat 2,5 $\times 5$ m területü, de a szalkszentmártoni méretezett rajzon ugyanez $3 \times 5,76 \mathrm{~m}$, a nyílások az első két esetben 1,9 m magasak, Szalkszentmártonban 2,3 m szerepel tollal, majd az áthúzva 2,1 m ceruzával.

192 Nyeregtetős harangfal széles nyílásokkal (Újtikoshoz, Pátrohához asszociálható): BTM KM ÉGy68.141.5_20, 22-24, 28., Móricgáthoz hasonló megoldások: 68.141.5_21. Szalkszentmártont idéző vízszintes, öt nyílással áttört oromzat: 68.141.5_51.

193 BTM KM ÉGy 68.138.38_2. (Szignált, datált), alagiként azonosított: 68.138.38_8-9, soroksári: 68.95.11 (1934), balatonlellei: 68.138.31_18. Vázlatrajzok: 68.141.5_44. Ennek egy változata, amikor a félköríves ablakot kereszttel tagolja, és aköré rendezi az ablak/fülkepárokat: 68.141.5_45-48, 58 .

194 Somogyi 1941, 54 utáni illusztrált oldal. A kiállítás koncepciója (ahogyan az 1934-es római kiállításé is) Gerevich Tibortól származott. Tóth 1985, 101, 109; Mezei 1985, 135, 141; P. Szücs 1985, 417.

195 Soproniként azonosított homlokzattervek: BTM KM ÉGy 68.138.45_1, 9-10, 23, 28, 31, 33-36, 66. Vázlatrajzok: 68.141.5_56-57.

196 Soproniként azonosított: BTM KM ÉGy 68.138.45 23, 28, 33-35, 66, 83. Balatonlellei: 68.138.31_38.

197 Részben emiatt is problematikus Gerjenben exonartexként értelmezni ezt a térszakaszt (ahogyan azt Urbán és Vukoszávlyev teszi), másrészt pedig az alaprajzok mindhárom esetben csupán egyetlen térszakaszt jelölnek, míg az exonartex lényege a nartex megkettőzése. (UrbánVukoszávlyev 2016, 21 és Vukoszávlyev-Urbán 2016, 289. A 35. és 88. lábjegyzet szó szerint egyezik.) A szerzőpáros szerint Gerjenben „Az (sic!) háromnyílásos árkáddal képzett bejárat mellé balra kihelyezett torony aszimmetrikus szerkesztése a (...) Wichinger Károly által tervezett pécsi Pálos templomot idézheti számunkra.” Másutt „,Az oldalra kihelyezett torony aszimmetrikus szerkesztése és az árkádos elötér motívuma Weichinger Károly pécsi temetőkápolnáját" juttatta eszükbe. (Urbán-Vukoszávlyev 2016, 288-289). Csakhogy az előbbinél a torony nem tapad az épülethez, hanem hármas árkádsor adja az átkötést, a homlokzat azonban kétárkádos, míg az utóbbi homlokzata valóban három félkörívvel nyitott, az azonban torony nélkül épült.

198 BTM KM ÉGy 68.138.31_34. (1942), csornai templom terve Uo. 68.138.1 (1934)

199 A kisbácsai templom jelenlegi kialakítása a toronynyal egyidős. L. 172. j.
200 Alagiként azonosított homlokzatterv: BTM KM ÉGy 68.138.38_7, homlokzatterv 68.141.5_58. (é. n.)

201 Latinkereszt osztású körablak: Balatonlelle 68.138.31_38. (1942); csornai templom terve Uo. 68.138.1 (1934) (kombinálva a kereszt alatt álló figurákkal) és vázlatok: 68.141.5_22, 28 .

202 Mohácsi ravatalozó tervei: BTM KM ÉGy 68.133.1_5 (1936-38); Állami gyerekmenhely kápolnája 68.96.1 (1947); Balatonlelle, ajtók részletrajzai: 68.138.31_14 (1948).

203 Balatonlelle, ajtók részletrajzai: 68.138.31_14 (1948); Mohácsi Fogadalmi templom, kiskapu rajza: 68.138.46.52 (1939).

204 BTM KM ÉGy 68.138.28_3. (1949), több vázlat is ismert hozzá: pl. 68.141.4_21-22. (é. n.) Mindkettő templomi vasrácsként azonosítva, miközben jól kivehetőek a kilincsek.

205 Lantos 2016b, 322. EFL AN AP 5945/1950. Gulyás levele 495/1950. VPKL AP Kiskunmajsa 2730/57. Palotás József káplán levele (isz. n.).

206 ÉM ÁB D 1962-es, 1966-os, illetve az 1964-ig, 1967 ig érvényes életrajzok és 1971-es kérelem.

207 A felsoroltak az 1962-es és 1964-ig életrajzból. Az 1971-es nyugdíj-megállapítási kérelemben a Fővárosi Tervező Intézet és a Városrendezési Intézet helyett a BUVÁTI, a KÖZTI helyett a LAKÓTERV szerepel.

208 Előbbi az 1964-ig, utóbbi az 1966-os illetve 1967-ig tartó életrajzokban és a kérelemben. ÉM ÁB D 1962-es és 1964-ig életrajz.

209 ÉM ÁB D 1967-ig tartó életrajz és kérelem.

210 „A Magyar Beruházási Bank tervezője és műszaki ellenőre, munkaideje alatt az egyház részére különböző szakértői munkákat végez." ÁBTL 3.1.5 O-14963/1/127. és 3.1.5. O-14963/1/278-279.

211 VPKL AP Kakucs 3592/1957, VPKL AP Móricgát 2054/1957, 4048/1957, VPKL AP Szalkszentmárton 3936/1957. Ugyanakkor Árkay „a Bányászati tervező Intézet építészmérnök csoportjának vezetője"-ként egy, az Állami Egyházügyi Hivatalhoz írt levelében így fogalmaz: „a fenti üggyel szívességből foglalkozom, mert nincs senkiök, aki az anyagigénylést elintézné". MNL OL XIX-A-21-b Inárcs, 1958.

212 VPKL AP Kakucs 56/1958. iratcsomó.

213 HD Kiskunmajsa 120. VPKL AP Kiskunmajsa 2073/1958. Májusban kapta meg Árkay a megbízást, de az állványzat megszerzésének nehézkessége miatt a munka csak 1959-ben indult meg.

214 BTM KM ÉGy 68.107.1-2. (é. n.)

215 Kömpöci oltár: 1957. HD Kiskunmajsa 120, Hernádé 1963. VPKL AP Hernád 3136/1963. Bányai levele 12/1963.

216 Jakabszállás: BTM KM ÉGy 68.141.1_2 (é. n., de kivehető Árkay felirata: 62. XI. 15), Kömpöc padjai és szentélyrácsa (1955. HD Kiskunmajsa 119): 68.141.1_3, Tápiószentmárton kovácsoltvas falikar: 68.141.3_11 (1954).

217 VPKL AP Kakucs 859/1958. A püspöki helynök levele, VPKL AP Szalkszentmárton 461/1958 Regőczy István levele isz. n. ad-461/1958.

218 Itt azért nem sorolom fel a kisbácsai templom tervezését is, mert úgy tudni, hogy annak terve nem megrendelésre készült, hanem Árkay ajánlotta fel a győri püspöknek. Takács 2008, 10-11. 
219 ÁBTL 3.1.5. O-14963/1/278-279. 278. ÉM ÁB D Kérelem.

220 BTM KM ÉGy 68.138.34_1-2, 4, 5 (1959).

221 BTM KM ÉGy 68.40.25_6-10, 12-17.

222 Zeleméri 1930, 50.

223 Urbán-Vukoszávlyev 2016, 39 szerint Árkay „mint legismertebb »templomépítő « szaktudása meghatározó volt korszakának”, aki „,a katolikus egyház vezető köreiben mozogva számos egyházmegyei építésszel tarthatta a "nem hivatalos « kapcsolatot". Az általuk megkeresett építészek közül Vándor Ferenc a veszprémi, Mezős Mi- hály a kalocsai egyházmegye alkalmazásában állt, Árkay viszont a pécsi, győri, váci és egri egyházmegyéknek tervezett. Márkus Béla ugyan az Egri Főegyházmegyének dolgozott (Maklár építése: 1947-1950. EFL AN AP Maklár 1764/1979; Kerecsend terve: 1948. Kerecsend, pélébániai irattár), de ekkor Árkay még csak külsősként tervezte Hort templomát. (Lantos 2016, 321.)

224 Genthon 1929, 877.

225 Lásd fentebb Sopron és Alag templomépítéseit.

226 Gábor 1977, 13.

227 Csáki 2003, 52.

\section{RÖVIDÍTÉSEK}

ÁBTL - Állambiztonsági Szolgálatok Történeti Levéltára, Budapest

BTM KM Égy - Budapesti Történeti Múzeum, Budapest. Kiscelli Múzeum, Építészeti gyüjtemény

EFL AN AP - Egri Főegyházmegyei Levéltár, Eger. Archivum Novum, Acta Parochiarum

EKM - Esztergom, Keresztény Múzeum

ÉM ÁB D - Építészeti Múzeum, Budapest. Árkay Bertalan Dokumentumai

HD - Historia Domus

MNL OL - Magyar Nemzeti Levéltár, Országos Levéltár, Budapest

MNL PML - Magyar Nemzeti Levéltár Pest megyei Levéltára, Budapest

VPKL - Váci Püspöki és Káptalani Levéltár, Vác

VPKL AP - Váci Püspöki és Káptalani Levéltár, Vác. Acta Parochiarum

ZM-SZK - Zempléni Múzeum, Szerencsi Képeslapgyưjtemény, Szerencs

é. n. - év nélkül

isz. n. - iratszám nélkül

s. n. - név nélkül

s. p. - oldalszám nélkül

\section{IRODALOM}

Balog 2005 - Balog Éva: Lőrinci. R. k. templom, R. k. kápolna. In: Bardoly István - Haris Andrea szerk.: Magyarország műemlékjegyzéke. Heves megye. Budapest 2005, 118-119.

Barla-Szabó 1992 - Barla-Szabó László: Árkay Bertalan. In: Saur Allgemeines Künstler-Lexikon Bd. 5. ArdosAvogaro. München-Lepizig 1992, 100-101.

Biczó 2007 - Biczó Zalán: „Bemegyek szent templomodba". A XX. században épült templomok a Győri Egyházmegyében. Győr 2007.

Bíró 2010 - Bíró Aurél: A Clark Ádám által tervezett sashegyi Weber/Saxlehner-palota kápolnájának pusztulása. Magyar Sion 4/46. 2010: 2, 233-242.

Csáki 2003 - Csáki Tamás: Árkay Bertalan és Peter Behrens bécsi mesteriskolája. Müvészettörténeti Értesítő 52. 2003, 27-63.

Cséfalvay 1988 - Cséfalvay Pál: Egyházi építészet. In: Turányi László szerk.: Magyar Katolikus Almanach II. A magyar katolikus egyház élete 1945-85. Budapest 1988, 461-463.

Farkas 1991 - Farkas Attila: Régit és újat hozz elő. A hazai szakrális építészet fél évszázada. Magyar Építőművészet 82. 1991: 4, 2-3.

Gábor 1977 - Gábor Eszter: A Római Iskola építészete. Müvészet 18. 1977: 12, 11-15.

Genthon 1929 - Genthon István: Képzőmüvészeti Szemle. Napkelet 7. 1929: 24, 874-877.
Hartmann 2016 - Hartmann Gergely: Templomaink tegnap és ma. Győr-Moson-Sopron megye templomépítészete 1897-2004. Győr 2016.

Kelényi 2013 - Kelényi György: Típustervek a magyar későbarokk építészetben. In: Szentesi Edit - Mentényi Klára - Simon Anna szerk.: Kö kövön. Dávid Ferenc 73. születésnapjára. Budapest 2013, 485-494.

Kovács 2010 - Kovács Dániel: Modern templomépítészet Magyarországon a II. világháború után. In: Wesselényi-Garay Andor szerk.: A mindenség modellje. 2. bővített kiadás. Debrecen 2010, 17-24.

Láng 2008 - Láng András: Taksony - Quinquagenarium. A Szent Anna templom felszentelésének 50. évfordulójára. Krisztus Fénye 9. 2008: 3, 11-17.

Lantos 2009 - Lantos Edit: Római katolikus templomépítészet Magyarországon 1945 után. Az 1945 és 1957 közti időszak. Művészettörténeti Értesítő 58. 2009, 223-244.

Lantos 2014 - Lantos Edit: Az 1945 utáni iskolatervezés. Típustervek és egyedi épületek. Müvészettörténeti Értesítő 63. 2014: 2, 373-396.

Lantos 2016a - Lantos Edit: „Szabad vallásgyakorlatot biztosít alkotmányunk minden becsületes dolgozónak." Az egyházi építkezésekre vonatkozó kérelmek, érvelések, azok alapja és háttere 1957 és 1960 közt. Korall. Társadalomtörténeti Folyóirat 64. 2016, 90-109.

Lantos 2016b - Lantos Edit: Bauhaus? Modern barokk? Árkay Bertalan Horton (1954) és Taksonyban (1958) 
épült templomainak építéstörténetei és tervei. Művészettörténeti Értesítő 65. 2016, 319-343.

Lôvei 2000 - Lôvei Pál: Javaslatok a 20. század építészeti emlékeinek védelmére. In: Uő szerk.: A műemlékvédelem táguló körei. az Országos Müemlékvédelmi Hivatal kiállítása, 2000. április 17 - július 16. Budapest 2000, 74-90.

Major 1983 - Major Máté: Építészettörténeti és építészetelméleti értelmező szótár. Budapest 1983.

Mezei 1985 - Mezei Ottó: Kiállítások. In: Aradi Nóra főszerk., Kontha Sándor szerk.: Magyar müvészet 1919-1945. Budapest 1985, 132-144.

P. Szücs 1985 - P. Szǘcs Julianna: A római iskola. In: Aradi Nóra főszerk., Kontha Sándor szerk.: Magyar müvészet 1919-1945. Budapest 1985, 412-442.

Prakfalvi 2002 - Prakfalvi Endre: Római katolikus templomok. Budapest 2002.

Prakfalvi 2004 - Prakfalvi Endre: A hatvanas évek építészetéről. In: Rainer M. János szerk.: „Hatvanas évek” Magyarországon. Tanulmányok, 2 kötet. Budapest 2004, 1. kötet, 474-505.

Pusztai 1972 - Pusztai László: Árkay Bertalan (1901-1971) Magyar Építőművészet [IC] 1972: 5, 60-61.

Regőczi 1988 - Regőczi István: Isten vándora. Budapest 1988.

Reisner 2013 - Reisner Erzsébet szerk.: Isten hajléka az emberek között. A soproni Szent István templom, 1943 2013. Sopron 2013.

Rév 1987 - Rév Ilona: Templomépítészetünk ma. Budapest 1987.

Somogyi 1941 - Somogyi Antal: Modern magyar egyházi építészet. Szépmüvészet 2. 1941: 3. 54-57.

Szabó 1958 - Szabó Erzsébet: Vecsés. In: Dercsényi Dezső szerk.: Pest megye müemlékei II. Budapest 1958, 389-391.
Szekeres-Virág 1982 - Szekeres-Virág Judit: Árkay Bertalan. Müemlékvédelem 26. 1982: 2, 146-149.

Takács 2008 - Takács Istvánné: Ötvenéves az Isten háza Kisbácsán. Győr 2008.

Tóth 1985 - Tóth Antal: A müvészet támogatásának formái. In: Aradi Nóra főszerk., Kontha Sándor szerk.: Magyar müvészet 1919-1945. Budapest 1985, 92-115.

Tölgyes 1999 - Tölgyes Orsolya: Árkay Bertalan. In: Fitz Péter főszerk.: Kortárs magyar művészeti lexikon. Budapest 1999, 78 .

Urbán-Vukoszávlyev 2016 - Urbán Erzsébet - Vukoszávlyev Zorán: Árkay Bertalan templomépítészete a második világháború után. Architectura Hungariae 15. 2016: 1, 7-42.

Vákár 1982 - Vákár Tibor: Templomépítés és környezet. Magyar Építőmüvészet [IC] 1982: 3, 60-63.

Varga 1997 - Varga Lajos: A Váci egyházmegye történeti földrajza. Vác 1997.

Vukoszávlyev-Urbán 2016 - Vukoszávlyev Zorán - Urbán Erzsébet: Magyarország templomépítészete 1945-1964 között. Vázlat az alkotóművészi értékeléssel megállapítható építészeti folytonosságról. Építés - Építészettudomány 44. 2016: 3-4, 247-315.

Winkler-Domján 2010 - Winkler Barnabás - Domján Kornélia szerk.: Posztumusz Ybl Miklós-díj 2010. Budapest 2010.

Zeleméri 1930 - Zeleméri Rudolf: A Győr-Gyárvárosi új róm. kath. templom. Magyar Iparművészet 33. 1930: 3-4, 49-60.

Zsédely 2008 - Zsédely Gyula: A „Magyarok Nagyasszonya” iskolakápolna a Szent József iskolában (1936-1978) és a plébánia. A nagy küzdelem és a „Magyarok Nagyasszonya" kápolna építéstörténete (1978-1988). In: Surányi Dezső szerk.: Magyarok Nagyasszonya Kápolna és az Újplébánia története. Cegléd 2008. 61-75.

\section{ENUMERATION AND EVALUATION. BERTALAN ÁRKAY'S POST-1945 (USQUE) 12 CHURCHES}

The paper presents Bertalan Árkay's post-1945 smaller churches and through them the architect's formal solutions and working method on the basis of plans in the estate, archival sources and his own list of works. After a source critical collation of the listed sources, the author takes stock of the elements of the oeuvre and identifying the buildings attributed to Árkay she clarifies the size of the oeuvre. She has found that between 1945 and 1953 he planned three churches (Cegléd, Gerjen, Kömpöc) but the construction of the Cegléd church was interrupted by the historical circumstances. Between 1957 and '60 he made plans for nine churches (Győr-Kisbácsa, Szalkszentmárton, Vecsés Andrássy-telep, Hernád, Inárcs, Móricgát, Tiszalök, Újtikos, Vecsés-Óplébánia) seven of which were constructed on his plans. In 1961-65 he planned and built the churches of Pátroha, Parádsasvár and Tiszaeszlár. After the identification of restoration work and the contributions of other architects, it could be concluded that in addition to the churches of Hort and Taksony Bertalan Árkay saw 12 of his planned churches built up.

The examination of the buildings and the plan drawings confirmed that Árkay had some favourite formal solutions that he was wont to resort to. Regarding the façade design, three versions can be differentiated: one with a façade tower, one with a gable wall, and one with a pediment. As for window types, he had a penchant for windows with circular head, windows/French windows designed upon the arms of the cross and rosettes subdivided with a cross. Comparing them to the material in the estate one finds that Árkay often reused his motifs designed 20-25 years earlier. Behind the repeated forms of details (portals, choir) collaboration with the same craftsmen can be discerned.

By correcting some facts of the biography the author clarifies that apart from his work in state planning of fices, Bertalan Árkay accepted several ecclesiastical commissions. It also came to light that in addition to planning new buildings he often undertook the restoration of buildings and the designing of objects of furnishing in any style.

The final conclusion is that after 1945 Bertalan Árkay was not able to repeat the architecture historical bravura he achieved with the Városmajor church, the prelude to modern Hungarian church architecture, designed with 
his father Aladár Árkay. In aesthetic terms his smaller churches satisfy the standards of ecclesiastic art and the expectations of the users, but their historicizing elements remove them from the contemporary trends of architecture, and their repetition shows routine rather than architectural invention.

LANTOS Edit művészettörténész, MTA KIK Magyar Tudományos Müvek Tára / art historian, Library and Information Centre of the Hungarian Academy of Sciences,
Hungarian Scientific Bibliographic Database, lantos. edit@hotmail.com

Kulcsszavak: Árkay Bertalan, Csaba László, Gerevich Tibor, római katolikus templom, templomépítészet, egyházi épületek, templomtervezés, tervezői stratégiák, ötvenes évek, hatvanas évek, 1945 után / Keywords: Bertalan Árkay, László Csaba, Tibor Gerevich, Roman Catholic Church, Church architecture, Religious buildings, church planning, Planning strategies, 1950s, 1960s, postwar 